\title{
The interaction of tectonics, climate and eustasy in controlling dolomitization: A case study of Cenomanian-Turonian, shallow marine carbonates of the Iberian Basin
}

DOI:

10.1111/sed.12704

Document Version

Accepted author manuscript

Link to publication record in Manchester Research Explorer

Citation for published version (APA):

Newport, R., Segura, M., Redfern, J., \& Hollis, C. (2020). The interaction of tectonics, climate and eustasy in controlling dolomitization: A case study of Cenomanian-Turonian, shallow marine carbonates of the lberian Basin. Sedimentology. https://doi.org/10.1111/sed.12704

\section{Published in:}

Sedimentology

\section{Citing this paper}

Please note that where the full-text provided on Manchester Research Explorer is the Author Accepted Manuscript or Proof version this may differ from the final Published version. If citing, it is advised that you check and use the publisher's definitive version.

\section{General rights}

Copyright and moral rights for the publications made accessible in the Research Explorer are retained by the authors and/or other copyright owners and it is a condition of accessing publications that users recognise and abide by the legal requirements associated with these rights.

\section{Takedown policy}

If you believe that this document breaches copyright please refer to the University of Manchester's Takedown Procedures [http://man.ac.uk/04Y6Bo] or contact uml.scholarlycommunications@manchester.ac.uk providing relevant details, so we can investigate your claim.

\section{OPEN ACCESS}




\title{
THE INTERACTION OF TECTONICS, CLIMATE AND EUSTASY IN CONTROLLING DOLOMITIZATION: A CASE STUDY OF CENOMANIAN-TURONIAN, SHALLOW MARINE CARBONATES OF THE IBERIAN BASIN.
}

Richard Newport ${ }^{1}$, Manuel Segura ${ }^{2}$, Jonathan Redfern, ${ }^{1}$ Cathy Hollis ${ }^{1}$

${ }^{1}$ School of Earth and Environmental Sciences, Manchester University, Manchester, M13 9PL.

${ }^{2}$ Stratigraphy Unit, Departamento de Geologıca, Universidad de Alcala, 28871 Alcala de Henares, Madrid, Spain. Associate Editor - Jody Webster

Short Title - Controls on dolomitization, Iberian Basin

\begin{abstract}
During the Cretaceous, high global sea-level and low latitudinal temperature variations led to the growth of epeiric carbonate platforms. Platform-scale dolomitization of these platforms is not common, reflecting the low $\mathrm{Mg} / \mathrm{Ca}$ ratio of seawater and a humid climate. This study describes the processes governing pervasive dolomitization of a land-attached carbonate platform within the Iberian Basin. Dolomite is planar to sub-planar with a geochemical signature consistent with dolomitization from penesaline seawater. Dolomitization was most pervasive during a 1 My period in the middle Cenomanian, by repeated reflux of seawater from brine pools formed on the top of a southward-prograding carbonate platform. Tilting and structural reorganisation in the Upper Cenomanian led to a reversal in polarity of the platform, and dolomitization was restarted by the northwards reflux of seawater. Rising relative sea-level and oceanic acidification led to back-stepping of the platform such that the supply of dolomitising fluids was cut off. In the Lower Turonian, pervasively dolomitized rudist rudstone facies in the south of the study area indicate that dolomitization restarted, either penecontemporaneously or later, from highly evaporated Campanian-Maastrichtian seawater.

A systematic increase in dolomite crystal size up-section ties broadly, but not entirely, to stratigraphy. It is possible that these textural differences reflect changes in fluid chemistry, limestone permeability or precursor rock texture. However, the lack of stratigraphic conformance, and the preservation of the earliest-formed dolomite only in the oldest sediments, could indicate a progressive recrystallization of early-formed dolomite through repeated reflux of brines. As such, the succession appears to preserve a fossilized record of dolomite recrystallization through time during the Cenomanian - Turonian. The results of this study therefore provide a record of the progressive dolomitization of a carbonate platform and demonstrate the important interplay of climate and basin-scale tectonics on dolomite distribution and crystallinity.
\end{abstract}


Keywords: Dolomite, penesaline seawater, reflux dolomitization, Cenomanian, Turonian

\section{INTRODUCTION}

Dolomitization is one of the most comprehensively studied, yet still poorly understood, processes in sedimentology. Dolostone is of particular importance because it is a host rock for hydrocarbon, water and mineral resources (lannace et al., 2011). Near-surface, platform-scale dolomitization, which occurs prior to significant burial of many carbonate sediments is largely ascribed to the reflux of seawater from brine pools formed on the top of carbonate platforms (Warren, 2000; Machel, 2004). Many case studies do not, however, take full account of the influence of allogenic controls, such as climate, tectonism and hydrology, even though they can influence the composition, supply and drainage of dolomitizing fluids. Conversely, reactive transport models have provided insight into the processes governing dolomitization, but only a few have been compared to natural datasets (e.g. Garcia-Fresca et al., 2009, 2012; Al Helal et al., 2012).

The Iberian Basin of northern Spain provides an excellent locality to investigate how relative sealevel and basin-scale tectonics interacted to control the extent of dolomitization on a carbonate platform (Figs 1 and 2). The well-exposed succession of shallow marine, Cretaceous strata allows the distribution of dolostone to be mapped in order to spatially and temporally delineate its distribution. In the Cretaceous, the Iberian Basin formed a narrow, shallow seaway that was periodically connected to the northern Atlantic Ocean and southern Tethys Ocean (Floquet, 1991, 1998; Figure 1). During this time, relative sea-level rose to its maximum for the entire Phanerozoic (Haq et al., 1987; Segura et al., 1993a; Garcia et al., 1993, 1996; Gil et al., 2006; GarciaHidalgo et al., 2007), whilst tectonic activity in the western Mediterranean led to a dramatic rearrangement of the Iberian Plate, and a change in the basin architecture (Floquet, 1991; Alonso et al., 1993, Gimenez et al., 1993, Caus et al., 2009). This paper presents the results of a detailed study of the region, using outcrop, petrographical and geochemical data, to fully assess the controls on dolomitization of Cenomanian-Turonian strata of the Iberian Basin. It allows analysis of how changes in relative sea-level and basin architecture has affected the distribution of dolomite within shallow marine strata.

\section{GEOLOGICAL SETTING}

During the Cenomanian, the Iberian Basin was characterized by a narrow, shallow seaway that extended across the Iberian Peninsula, flanked to the west by the Hesperian Massif and to the east by the Ebro Massif (Fig. 1) (Floquet, 1991; Alonso et al., 1993; Garcia-Hidalgo et al., 2007). The Atlantic Ocean and the Tethys Ocean were separated by a land bridge in the centre of the basin, known as the Seuil High, which was drowned during the lower and uppermost Cenomanian (Figure 1) (Floquet, 1991; Alonso et al., 1993; Wilmsen, 2000). Sea floor spreading in the Bay of Biscay during the Upper Cenomanian led to rotation of the entire Iberian Peninsula and tilting towards the north-west (Garcia-Mondejar, 1996; van Wees et al., 1998). This tilting resulted in exposure 
of the southern part of the Iberian Range and Betic Basin (Floquet, 1991; Alonso et al., 1993; Martin-Chivelet, 1995) and increased subsidence in the Basque-Cantabrian Basin (Platzman and Lowrie, 1992). At this point, the Atlantic Ocean and Tethys Ocean became separated, with flooding of the Iberian Basin from the Atlantic Ocean to the north.

During the Cenomanian, the Iberian Basin was situated within a semi-arid climate belt (RodriguezLopez et al., 2006, 2008) which moved northwards during the Upper Cretaceous, as the North and South Atlantic Ocean became connected (Chumakov et al., 1995). Mean sea surface temperatures in the Iberian Basin have been estimated to be as high as $30^{\circ} \mathrm{C}$ (Schouten et al., 2003; Steuber et al., 2005). The peninsula was also subject to a complex wind pattern, primarily directed from the west (Fig. 1; Poulsen et al., 1998). It has been suggested that this wind pattern, coupled with the palaeo-topography of the area, could have led to a significant rain shadow effect in the southern and central parts of the basin (Rat, 1989).

The Upper Albian to Middle Turonian succession was deposited in the Iberian Basin during the UZA 2 global sea-level rise of Haq et al. (1987). It can be split into five $3^{\text {rd }}$ order transgressive-regressive (T-R) cycles (UZA 2.1 to 2.5) traditionally referred to as lithostratigraphic formations as defined by Segura et al. (1993a) and adopted in this study. In the summary below, lithostratigraphic units are referred to in brackets and are also compared to the sequence stratigraphic framework in Fig. 3. The UZA 2.1 to 2.2 (basal Utrillas Formation) is composed of upwards-fining continental sandstones (Floquet, 1998) and is unconformably overlain by shallow marine, subtidal carbonates of UZA 2.3 (Santa Maria de las Hoyas Formation), dated as lower to middle Cenomanian (Garcia et al., 1993; Floquet, 1998; Figure 3 - 4). To the west of the Iberian Basin the carbonate platform transitions into coarse-grained, well-sorted sandstones (Garcia et al., 1993; Gimenez et al., 1993; Newport, 2014). UZA 2.4 (Villa de Ves Formation) has a sharp, conformable contact with UZA 2.3 (Garcia et al., 1996), whilst the top of this unit is defined by a subtle exposure surface, which truncates the uppermost parasequence on the northern margin with the Seuil High (Figs 3 and 4; Garcia et al., 1993, Gimenez et al., 1993; Gil et al., 2004). The unconformity is overlain by UZA 2.5 (Picofrentes Formation) which contains common oysters, planktonic forams and ammonites, indicative of an upper Cenomanian age (Floquet, 1991; Alonso et al., 1993; Segura et al., 1993a, b; Garcia-Hidalgo et al., 2007; Peyrot et al., 2011). It is differentiated here as UZA 2.5 T, whilst the overlying succession (equivalent to the Ciudad Encantada Formation) is termed UZA 2.5 R. The upper UZA 2 boundary is interpreted at the top of the Lower Turonian (Ciudad Encantada Formation; Segura et al., 1993b).

\section{METHODS}

Fifteen sections, ranging from 9 to 141 metres in thickness of Cenomanian to Turonian sediments were logged and systematically sampled using traditional field logging methods (Fig 2; Table 1). 400 samples were collected, 
of which 200 were prepared as $30 \mu \mathrm{m}$ covered thin sections that were stained with potassium ferricyanide and alizarin red S (Dickson, 1966), to identify ferroan cements and differentiate calcite and dolomite, and impregnated with blue resin to highlight porosity. Crystal size measurements were conducted using Petrog( point counting software and a stepping stage; 250 points were counted per section. A subset of 40 samples were prepared as unstained, polished and uncovered sections. Cathodoluminescence $(C L)$ analysis was carried out using an Olympus BH-2 microscope (Olympus, Tokyo, Japan) attached to a Citl 8200 mark-2 cold cathodoluminescence machine (CITL, Hertfordshire, UK) at an accelerating voltage of 10 to $12 \mathrm{kV}$, a vacuum of 0.2 Torr and a cathode current of between 310 to $335 \mu \mathrm{A}$.

Rock powders for X-ray diffraction (XRD), isotopic and trace element analysis were collected using a Dremel microdrill. The smallest microdrill bit available was $0.7 \mathrm{~mm}$ diameter, restricting microsamples to crystals $\gg 0.5 \mathrm{~mm}$. Approximately $1 \mathrm{~g}$ of each sample was reacted in $5 \mathrm{ml}$ of $1 \mathrm{M}$ sodium acetate $\left(\mathrm{CH}_{3} \mathrm{COONa}\right)$ that was adjusted to $\mathrm{pH} 5$ using $1 \mathrm{M}$ acetic acid $\left(\mathrm{CH}_{3} \mathrm{COOH}\right)$. Purity of remaining samples was then checked using XRD at the University of Manchester using a Bruker D8 advanced instrument (Bruker, Billerica, MA, USA) and Cu $\mathrm{K}_{\alpha 1}$ radiation. Data was collected over a range of $5^{\circ} 2 \theta$ to $70^{\circ} 2 \theta$ with a step size of $0.02^{\circ} 2 \theta$. Standards of known composition were run prior and post data collection to ensure accuracy. Quantification of mineral composition was carried out using Siroquant software which uses the intensities and area under peak of XRD results to determine the percentage of each mineral within the sample. Stoichiometry of the sample was calculated using the method proposed by Lumsden (1979).

Stable oxygen and carbon isotope analysis was conducted on $0.30 \mathrm{mg}$ of samples dissolved in phosphoric acid and analyzed using a ThermoFinnigan MAT 253 mass spectrometer attached to a Gasbench II and a PAL auto sampler (Thermo Fisher Scientific, Waltham MA, USA). All values are reported relative to the Vienna Pee Dee belemnite (VPDB). Certified carbonate standards NBS 19, CO-1, CO-8 and an internal standard (RUB) were used to ensure accuracy and precision of analysis. Standard deviations are $0.4 \%$ and $0.15 \% 0$ for carbon and oxygen respectively. The concentration of the $\mathrm{Ca}, \mathrm{Mg}, \mathrm{Fe}, \mathrm{Mn}$ and $\mathrm{Sr}$ was determined using a Thermo Scientific iCAP 6500 DUO inductively coupled plasma optical emission spectrometer (ICP-OES) (Thermo Fisher Scientific, Waltham MA, USA). Prior to analysis, approximately $0.15 \mathrm{mg}$ of sample was dissolved in $3 \mathrm{M} \mathrm{NHO}_{3}$ and then diluted using $2 \mathrm{ml}$ of deionized water $\left(>18.2 \mathrm{M} \Omega \mathrm{cm}^{-1}\right)$. Reference samples BSC-CRM-512, dolomite and BSCCRM-523, limestone were run as standards. The relative standard deviation (\%RSD) was $<5 \%$ for all elements and samples.

Measurements of Sr isotope values were carried out at the SGIker-Geochronology and Isotopic Geochemistry facility of the University of the Basque Country UPV/EHU (Spain). The procedure for sample treatment and extraction of Sr was carried out according the method of Pin and Bassin (1992) and Pin et al. (1994). The ${ }^{87} \mathrm{Sr} /{ }^{86} \mathrm{Sr}$ ratios were measured by MC-ICP-MS using a high-resolution Thermo Fisher Scientific Neptune instrument in static multicollection mode (Thermo Fisher Scientific, Waltham MA, USA), and corrected 
for mass fractionation by normalization to ${ }^{88} \mathrm{Sr} /{ }^{86} \mathrm{Sr}=8.375209$ (Steiger and Jager, 1977). The uncertainty for individual measurements of ${ }^{87} \mathrm{Sr} /{ }^{86} \mathrm{Sr}$ isotopes and average ratio under the same conditions for NBS-987 standard over the period of analyses was $0.710269+/-0.000015$ (2 SD).

\section{RESULTS}

\section{Sedimentological framework}

The sedimentological framework described and interpreted here is a summary of a larger study (Newport, 2015), which builds upon extensive prior sedimentological analysis of the Iberian Basin (Floquet, 1991; Gimenez et al., 1993; Garcia et al., 1996; Gil et al., 2006; Garcia-Hidalgo et al., 2007). The oldest sediments within the study area (UZA 2.3) on the eastern side of the basin comprise herringbone and trough cross-bedded, medium-grained to coarse-grained, well-sorted sandstone. These beds are overlain by dolomitized, microbial bindstone. Most of the succession, is dominated by skeletal wackestone and packstone, with abundant miliolid foraminifera and dasycladacean algae. There is a sharp and conformable contact with UZA2.4, which is pervasively dolomitized, but with some fabric retention observed in outcrop. It comprises a basal, upward-cleaning succession of microbial laminites overlain by oolitic grainstone, exhibiting an increase in grain size and decrease in mud content. There is an increase in the volume of cleaner, grainier facies from north to south (Fig. 4). Approximately 10 stacked, $1 \mathrm{~m}$ thick successions of oolitic grainstone are each capped by gastropod and foraminiferal wackestone and microbialites, with tepee structures and mud cracks. The upper parasequence of UZA 2.4 is absent, either removed by erosion or not deposited because of platform emergence. The thickness and volume of skeletal pack-grainstone, increases to the south. The top of UZA 2.4 is defined by minor brecciation, rip-up clasts, rhizoliths and vuggy, calcite-cemented porosity.

The basal, UZA 2.5 (UZA 2.5T) is defined in the south of the Iberian Basin by skeletal packwackestones, oolitic pack-grainstones and thin, algal laminated bindstones. These have, locally been completely obscured by fabric-destructive dolomitization. There is a northwards transition into skeletal wackestone with planktonic foraminifera and echinoid debris-(Fig. 4). Eventually, the entire succession, across the basin, becomes dominated by nodular skeletal wackestones with oysters, ammonites and planktonic foraminifera. Basinwide, the succession culminates with a lime mudstone to wackestone with planktonic foraminifera, echinoid debris and articulated oysters. Locally, a thin, black, mudrock occurs, which is rich in ammonites.

The uppermost UZA 2.5 (UZA2.5R) shows a rapid increase in grain size and skeletal abundance. In the southern part of the study area, it is pervasively dolomitized with abundant biomoulds, after rudists, with large northward dipping, downlapping clinoforms (tens of metres in scale). The succession is capped by an irregular brecciated surface and palaeosols, which can be mapped regionally. To the north, the succession passes into fine-grained limestones and marls (Fig. 3 to 4 ). 


\section{Dolomite textures}

Based on petrographical analysis, five principal dolomite petrotypes were observed. All have planar fabrics (sensu Sibley and Gregg, 1987), exhibit unit extinction and are cross-cut by stylolites (Tables 2 and 3).

\section{Type $i$ and ii dolomite}

Type (i) dolomite is a clear, fine to medium crystalline (50 to $75 \mu \mathrm{m}$ ), planar-e to, rarely, planar-p dolomite that selectively replaces micrite matrix whilst skeletal grains remain intact or are dissolved (Fig. 5A and B). It comprises $<10 \%$ of the total rock volume, usually forming floating rhombs in a micrite matrix. It preferentially replaces burrows that have occasionally been completely dolomitized. Under CL, Type (i) dolomite is dull orange to non-luminescent with a mottled appearance and no zonation (Fig. 5C and D). Type (ii) dolomite is a fine to medium crystalline ( $\sim 50$ to $100 \mu \mathrm{m}$ ), euhedral, dull orange to non-luminescent dolomite cement that lines, but only rarely fills ( $<5 \%$ of dolostone volume), vuggy, fracture and mouldic porosity (Fig. $5 E$ ). Due to the relatively minor and diffusely distributed volume of type i and ii dolomite, it was not possible to isolate sufficient material for geochemical analysis.

\section{Type iii dolomite}

Type iii dolomite accounts for $90 \%$ of the dolomitized rock volume in the Cenomanian and can be split into three subtypes. Much of the succession comprises Type iii(a) dolomite, which is cloudy, finely crystalline ( 10 to 50 $\mu \mathrm{m})$ and completely replaces micrite within subtidal facies and algal laminites of the UZA2.4 and lowermost UZA 2.5. It has a dull orange to dull red-orange luminescence, with a mottled appearance and a complete lack of zonation (Fig. 6A and B). Bioclastic material is never preserved but precursor skeletal allochems are recognizable as biomoulds. In the upper parts of UZA 2.4 , a medium crystalline dolomite ( $\sim 50$ to $\sim 75 \mu \mathrm{m}$; Fig. $6 \mathrm{C}$ ) overprints Type iii (a) in patches, with no obvious control on its distribution. This is defined as Type iii (b) dolomite, since it has coarser crystallinity and a less cloudy appearance than Type iii (a), occasionally showing a cloudy core, clear rim morphology, and a dull red luminescence. Moulds within replacive type iii ( $a$ and b) dolomite are commonly lined by euhedral crystals of dolomite cement [Type iii (c)], measuring up to $175 \mu \mathrm{m}$ in size and showing dull red luminescence with very fine non-luminescent zones (Fig. 6B). This cement overgrows replacive dolomite. Similar cements also patchily occlude coarse-grained sandstones in UZA 2.3 (Fig. 6D).

The patchy distribution of Type iii (b) dolomite and the small size and isolated location of Type iii (c) dolomite cement means that it was not possible to confidently separate them for geochemical analysis. Therefore, the geochemical characteristics of Type (iii) dolomite are reported together. They have an average $\delta^{18} \mathrm{O}=-1.98 \%$ 。 PDB (-4.20 to $-0.94 \%$ 。PDB) and average $\delta^{13} \mathrm{C}=$ of $-0.16 \%$ VPDB (-1.93 to $1.94 \%$ VPDB; Fig. 7 ;

Table 3). Samples from the eastern side of the basin have lighter carbon and a wider range of lighter oxygen isotopic signatures within the uppermost UZA 2.4 (Fig. 7 and 8). Type iii dolomite has a range of compositions, 
from 48.5 to $57 \% \mathrm{CaCO}_{3}$, with an increase in $\mathrm{CaCO}_{3}$ upwards towards the top of UZA 2.4; many of the samples with higher concentrations of $\mathrm{Ca}$ exhibit depleted $\delta^{18} \mathrm{O}$ and $\delta^{13} \mathrm{C}$ and, in some cases, an increased crystal size (Fig. 8). Average concentrations of iron are relatively high ( $F e=972$ ppm; 1 to 1409 ppm), whilst manganese and strontium concentrations are low ( $\mathrm{Mn}=73 \mathrm{ppm} ; 34$ to $141 \mathrm{ppm}$ and $\mathrm{Sr}=88 \mathrm{ppm}$; 57ppm to 168ppm; Table 3; Figs 9 to 10). Samples with the lowest concentrations of Fe have the lightest $\delta^{18} \mathrm{O}$ and enriched concentrations of Ca (Fig. 9). To the north, on the Seuil High, much of the UZA 2.4 at Ventosa, Marazovel, Ciria and La Quinoneria has been dedolomitized. These samples have relatively light isotopic carbon $\left(\delta^{13} C=-5.4,-0.7\right.$ to $-8.1 \%$ ) and oxygen $\left(\delta^{18} \mathrm{O}=-7.4,-6.7\right.$ to $-7.6 \%$ o) and depleted iron $(5.1,0.4$ to $12 \mathrm{ppm})$ compared to dolomite $(n=6)$.

Average ${ }^{87} \mathrm{Sr} /{ }^{86} \mathrm{Sr}$ values of $0.70809(0.70758-0.70889)$ were measured in Type (iii) dolomite, with a moderate, positive correlation between ${ }^{87} \mathrm{Sr} /{ }^{86} \mathrm{Sr}$ and Fe concentration, $\mathrm{Sr}$ concentration and $\delta^{18} \mathrm{O}$ but no apparent correlation between $\mathrm{Mn}$ concentration and ${ }^{87} \mathrm{Sr} /{ }^{86} \mathrm{Sr}$ ratio (Fig. 10).

\section{Type iv dolomite}

Type iv dolomite occurs as a replacement and a cement. Type iv (a) dolomite is a fabric destructive, medium crystalline $(50$ to $100 \mu \mathrm{m})$, planar-e to planar-s replacive dolomite with a cloudy core and clear rim morphology (Fig. 11A and B). Under CL, it has a dull yellow/orange mottled luminescent core with a dull red rim that shows very fine dull red to non-luminescent zones (Fig. 11B). Type iv (b) dolomite is a non-luminescent cement, occasionally with sharp, bright luminescent subzones, that occludes remnant intercrystalline porosity. It comprises $5 \%$ of the total dolostone volume in the Cenomanian.

Although Type iv (a) crystals are up to $100 \mathrm{~mm}$ diameter - and therefore could be sampled, the patchy distribution of Type iv (b) dolomite means that it could not be confidently separated for geochemical analysis, and could have contaminated Type iv (a) samples. The data are therefore reported here collectively, but are considered to be representative of Type iv (a) replacive dolostone which is pervasive and . They have an average $\delta^{18} \mathrm{O}=-2.7 \%$ 。PDB (-3.3 to $-1.7 \%$ VPDB) and $\delta^{13} \mathrm{C}=2.64$ VPDB (1.3 to 3.8\% VPDB; Table 3; Fig. 7). Although crystal size increases upwards above the top of the UZA 2.4, there is no apparent associated change in $\delta^{18} \mathrm{O}$ or $\delta^{13} \mathrm{C}$ (Fig. 7). XRD analysis of two samples measured 50 to $55 \% \mathrm{CaCO}_{3}$ (Fig. 8). Average $\mathrm{Fe}=429 \mathrm{ppm}$ (208 to $551 \mathrm{ppm}$ ), $\mathrm{Mn}=61 \mathrm{ppm}$ (51 to $72 \mathrm{ppm}$ ) and $\mathrm{Sr}=68 \mathrm{ppm}$ (40 to 123ppm; Table 3; Figs 9 to 10 ) and ${ }^{87} \mathrm{Sr} /{ }^{86} \mathrm{Sr}$ values $=0.70823(0.70781-0.70866)$ were measured, but with a limited sample set it is difficult to determine co-variance between geochemical characteristics and ${ }^{87} \mathrm{Sr} /{ }^{86} \mathrm{Sr}$ ratio (Fig. 10). However, Type iv dolomite appears to show similar trends to Type iii dolomite, i.e. increasing Fe and decreasing Sr and $\mathrm{Mn}$ concentration and $\delta^{18} \mathrm{O}$ with increasing ${ }^{87} \mathrm{Sr} /{ }^{86} \mathrm{Sr}$ (Fig. 10). 


\section{Type $v$ dolomite}

Type $v(a)$ dolomite is highly fabric destructive, very coarsely crystalline (250 to $300 \mu \mathrm{m}$ ), planar-e to planar-s non-luminescent dolomite (Fig. $11 \mathrm{C}$ and D). It also forms clear, limpid, non-luminescent dolomite cement and lines intercrystalline and vuggy porosity [Type $v(b)$ ]. It comprises all the dolomitization seen in the Turonian UZA2.5R. Collectively, Type (v) has average $\delta^{18} \mathrm{O}=-3.7 \%$ VPDB (-4.3 to $-2.8 \%$ VPDB) and $\delta^{13} \mathrm{C}=3.3 \%$ VPDB ($0.3 \%$ to $5.5 \%$ o VPDB; Fig. 7). XRD analysis of 6 samples measured a narrow compositional range, $\sim 50 \% \mathrm{CaCO}_{3}$ in all but one sample (55\% $\mathrm{CaCO}_{3}$; Fig. 8). Fe concentrations average $185 \mathrm{ppm}$ ( 1 to $639 \mathrm{ppm}$ ), $\mathrm{Mn}=28 \mathrm{ppm}$ (12 to $52 \mathrm{ppm}$ ) and $\mathrm{Sr}=58 \mathrm{ppm}$ (38 to $111 \mathrm{ppm}$; Figs 9 to 10 ) whilst ${ }^{87} \mathrm{Sr} /{ }^{86} \mathrm{Sr}$ values average 0.70772 (0.70762 to 0.70783). Three samples show a moderate positive co-variance between $\mathrm{Fe}$ and ${ }^{87} \mathrm{Sr} /{ }^{86} \mathrm{Sr}$ ratio and a strong negative co variance between ${ }^{87} \mathrm{Sr} /{ }^{86} \mathrm{Sr}$ and $\mathrm{Mn}$ concentration and $\delta^{18} \mathrm{O}$ (Fig. 10).

\section{DISTRIBUTION OF DOLOMITIZED STRATA}

Dolomite types $\mathrm{i}$ and ii are only observed within the UZA 2.3 and the lowermost parts of UZA 2.4 and are not pervasive. To the east of the basin (in the Llumens, Ibdes and Embid de Ariza outcrops; Figure 3), Type i and ii dolomite are found in the uppermost 4 to $8 \mathrm{~m}$ of UZA 2.3 but thin northwards to around $2 \mathrm{~m}$ at Ciria (Figs 4 and 12). Type iii (a) dolomite then completely and pervasively replaces the entire UZA 2.4 as well as the lower parts of UZA 2.5 in the most westerly sections (Fig. 12). Type iii (b) dolomite is patchily distributed within the uppermost UZA 2.4. Type iii (c) dolomite is also observed within coarse-grained sandstones of upper UZA 2.2 in the western parts of the basin.

Type iv (a) replacive dolomite becomes systematically less abundant and pervasive from south to north across the basin. In the eastern transect, it pervasively replaces the mid to lowermost UZA 2.5 and the uppermost UZA 2.4 (Llumens and Ibdes sections; Figs 4 and 12). At Embid de Ariza (Fig. 3), floating rhombs of Type iv ( $a$ and $b$ ) dolomite are seen in the lowermost metre of UZA 2.5 but are not seen further north. In the west, Type iv (a) dolomite replaces the middle to upper parts of the UZA 2.5T, to the top of the exposed section. At the Siguenza and Ventosa sections, floating rhombs of Type iv ( $a$ and $b$ ) dolomite are seen in the lowermost $2 \mathrm{~m}$ of UZA 2.5 and are not seen further north (Fig. 12). Dolomite type $v(a$ and $b$ ) is seen exclusively within UZA 2.5R on the south-eastern side of the basin (Llumens, Ibdes and Embid de Ariza; Figs 3 and 12), where Type $v(a)$ is pervasive and fabric destructive.

Distinct stratigraphic trends are observed in the isotopic composition of dolomite. Beneath the top of UZA 2.4 there is a subtle decrease in $\delta^{18} \mathrm{O}$ from $\sim-1.5$ to $\sim-5.0 \%$ within Type iii dolomite (Fig. 8), with a similar, but also subtle trend for $\delta^{13} \mathrm{C}$. Type iv dolomite shows no obvious depth trends within UZA 2.5T. In UZA 2.5R, $\delta^{13} \mathrm{C}$ decreases and $\delta^{18} \mathrm{O}$ increases above the base of the formation. Samples of unaltered limestone from UZA 2.5T and UZA 2.3 have $\delta^{18} \mathrm{O}=-3.5$ to $-5.0 \%$ VPDB and $\delta^{13} \mathrm{C}=0.0$ to $+4.0 \%$ VPDB. 


\section{Calcite cement and dedolomite}

Fine to moderately crystalline calcite (up to $\sim 100 \mathrm{~mm}$ diameter) patchily occludes intercrystalline porosity. It is clear, colourless and limpid and forms subhedral non luminescent crystals, occasionally with bright luminescent subzones. Only two samples were analysed geochemically, recording $\delta^{13} \mathrm{C}=-6.1$ to $-7.13 \%$ and $\delta^{18} \mathrm{O}=-5.9$ to 7.3\%. Concentrations of Fe (0.9 to $1.7 \mathrm{ppm}$ ), $\mathrm{Mn}$ (0.3 to $1.9 \mathrm{ppm}$ ) and $\mathrm{Sr}$ (53 to $63 \mathrm{ppm}$ ) were low (Table 3).

Strata on the Seuil High, at Ventosa, Marazovel, Ciria and La Quinoneria (Fig. 3) are completely dedolomitized (Fig. 4). There is an upward increase in the volume of $\mathrm{CaCO}_{3}$ within successive beds throughout the UZA 2.4,as determined by XRD analysis, and in the uppermost $5 \mathrm{~m}$, beneath the sequence boundary. Partial dedolomitization ( $<20 \%$ of the total amount of dolomite) is observed in logged sections south of the Seuil High such as at Siguenza and Embid de Ariza. Dedolomite in these sections has a coarse crystal size of up to $1 \mathrm{~mm}$ and is non luminescent under CL. Samples of dedolomite have isotopically lighter carbon and oxygen, and lower concentrations of iron than Type iii (a) dolomite (Figs 7 to 9). Dedolomite is also observed at the top of individual parasequences within the middle to upper part of the UZA 2.4, which is sometimes associated with brecciation and karstification (Fig. 8). There is a clear, sharp unconformable contact between the dedolomite of UZA 2.4 and UZA 2.5T, with no dedolomitization observed in UZA2.5T,

\section{INTERPRETATION AND DISCUSSION}

\section{Depositional setting}

Trough and herringbone cross-bedding within the sandstone at the base of UZA2.3 suggests shallow marine tidal conditions at the base of the studied interval. The transition from to dolomitized microbial bindstone suggested a slight shallowing, and deposition of peritidal facies, but the abundance of miliolid foraminifera and dasycladacean algae within overlying beds indicates very shallow subtidal conditions were restored, marking the onset of growth of the carbonate platform in the Iberian Basin. Where dolomitization is fabric retentive in UZA2.4, stacked, metre-thick successions of oolitic grainstone, skeletal (gastropod-rich) wackestone and microbial bindstone indicates very shallow water conditions remained across most of the platform during the middle Cenomanian. The presence of gastropod-rich skeletal wackestone and microbial bindstone at the top of upward-shallowing successions, implies low energy intertidal sedimentation. Tepee structures and mud cracks indicate dessication during short-term emergence. The high abundance, low diversity assemblage and presence of microbialites within these peritidal facies is consistent with restricted circulation and elevated salinities, although no gypsum was observed. The increase in the volume of cleaner, grainier facies to south is consistent with moderate to high energy subtidal conditions, suggesting that the platform dipped to the south (Fig. 4). Truncation of the uppermost parasequences of UZA2.4 in the north, towards the Seuil High supports this 
interpretation. Emergence is interpreted to have longer-lived at the top of UZA 2.4, where brecciation is more developed and rhizoliths are present.

In the southern part of the Iberian Basin, skeletal and oolitic pack-wackestones and grainstones indicate that the platform was flooded at the base of UZA 2.5 with deposition under very shallow water marine conditions, passing into thin, supratidal facies (algal bindstones) to the south. The northwards transition into skeletal wackestone with planktonic foraminifera and echinoid debris demonstrates that water depths increased northwards, indicating a change in polarity of the carbonate platform (Fig. 4). This is consistent with plate reconstructions that indicate rotation of the Iberian microplate and associated tilting to the north-west (Floquet, 1991; Van Wees et al., 1998). Eventually, the entire succession, across the basin, becomes dominated by nodular skeletal wackestones with ammonites (Fig. 4), typifying open marine conditions. In this context, the thin, black mudrock is interpreted to be the uppermost UZA 2.5T (i.e. MF3 on Fig. 4) coincident with the Cenomanian Turonian boundary, and is thought to represent a condensed succession that was deposited during an Ocean Anoxic Event (OAE 2).

The marked increase in grain size and skeletal abundance within the upper part of UZA $2.5 \mathrm{R}$ suggests that the carbonate platform rapidly became re-established. In the south, the platform was dominated by rudists, and northward-dipping clinoforms indicate progradation of the platform as carbonate productivity increased. The platform remained in shallow water to the south, and became locally emergent, but passed northwards into deeper water over tens of kilometres (Fig. 4).

\section{Dolomitizing fluid and temperature}

Dolomitization within the Cenomanian-Turonian of the Iberian Basin is stratabound, and occurs over a large area (>100km x 100km; Fig. 2). All dolomite types show planar textures and uniform, unit extinction suggesting that dolomitization occurred at temperatures below $50^{\circ} \mathrm{C}$ (Sibley and Gregg, 1987). Types i and ii dolomite are diffusely distributed within UZA 2.3, and are often confined to burrows. These phases were too scarce and diffusely distributed to be isolated for geochemical analysis and so it is not possible to constrain the composition of the fluid responsible for their formation. However, their texture, crystallinity and luminescence are consistent with near-surface, low temperature formation and their occurrence within burrows suggests their formation was facilitated by organically-mediated processes during bioturbation (e.g. Gingras, 2004; Corlett and Jones, 2012).

Carbon isotopic data for Type iii, iv and $v$ dolomite have mostly marine values $\left(\delta^{13} \mathrm{C}=-2.2\right.$ to $5.5 \%$ o VPDB; Fig. 7) suggesting either dolomitization from seawater or rock-buffering of $\delta^{13} \mathrm{C}$ during dolomitization. There is a progressive enrichment in $\delta^{13} \mathrm{C}$ up-section from Type iii to Type iv to Type $v$ dolomite reaching a maximum $\delta^{13} \mathrm{C}=+5.5 \%$ at the base of the UZA $2.5 \mathrm{R}$ (Fig. 8). Carbon isotopic enrichment in diagenetic phases 
can be indicative of methanogenesis, which occurs at temperatures up to approximately $70^{\circ} \mathrm{C}$ (e.g. Raven and Dickson, 2006). Since mudstones at the top of UZA 2.5T would have been within the methanogenic window $\left(>55^{\circ} \mathrm{C}\right)$ during dolomitization of UZA $2.5 \mathrm{R}$, methanogenesis of organic matter could have been a source of enriched carbon. However, it is unlikely that this layer would have supplied sufficient volumes of enriched carbon to alter the $\delta^{13} \mathrm{C}$ of the dolomitic limestone, particularly since carbon isotopic values only record fluid composition at very high fluid-rock ratios (e.g. Banner et al., 1988). Instead, rock-buffering of carbon isotopic values is more likely, and hence the measured $\delta^{13} \mathrm{C}$ could reflect carbon isotopic enrichment in the precursor limestone. An increase in the $\delta^{13} \mathrm{C}$ of pure, unaltered marine carbonate has been noted at a number of locations across the globe at the Cenomanian-Turonian boundary, as a result of oceanic acidification during OAE2 (e.g. Jenkyns, 2010; Korbar et al., 2012). It has been suggested that the thin, dark, organic-rich mudstone that occurs beneath the Cenomanain - Turonian boundary is indicative of decreased carbonate productivity during oceanic acidification. The increase in $\delta^{13} \mathrm{C}$ recorded at the base of UZA $2.5 \mathrm{R}$ in the southern part of the study area could therefore reflect preservation of isotopically enriched marine carbon in the precursor limestone.

Holocene dolomite that has formed from seawater typically has Fe concentrations of 10 to 2000 ppm and Mn concentrations of 5 to 275 ppm (Gregg et al., 1992; Montanez and Read, 1992a; Smith and Dorobek, 1993). Type iii and iv dolomite generally have $\mathrm{Fe}$ and $\mathrm{Mn}$ within this range, although some are slightly enriched in Fe ( to > 4000 ppm; mean 600 ppm; Fig. 9), implying that fluids were occasionally enriched in Fe and suboxic to anoxic conditions were periodically developed (Fig. 7). The average concentration of Sr within Type iii dolomite $(88 \mathrm{ppm})$ is consistent with precipitation from seawater that has not reached gypsum saturation (estimated to be 100 ppm by Gregg et al., 1992; Montanez and Read, $1992 \mathrm{a}$, b). Trace element data is therefore suggestive of dolomitization from seawater, although ${ }^{87} \mathrm{Sr} /{ }^{86} \mathrm{Sr}$ isotope ratios of Types iii and iv dolomite are enriched relative to Cenomanian seawater (Fig. 10). The reasons for this are evaluated further below.

If dolomitization took place from seawater, and using the fractionation factor of Matthews and Katz (1977), dolomitization at $\sim 26^{\circ} \mathrm{C}$ is estimated for pristine Type iii dolomite $\left(\delta^{18} \mathrm{O}_{\text {dolomite }}=-0.9 \%\right.$ VPDB $)$. For Type iv, $\delta^{18} \mathrm{O}_{\text {dolomite }}=-3.3$ to $-1.7 \%$ o VPDB would equate to precipitation at 29.5 to $37^{\circ} \mathrm{C}$. Unaltered limestones of UZA 2.5R and UZA 2.3 have $\delta^{18} \mathrm{O}$ that are consistent with other Cenomanian limestones (Scholle and Arthur, 1980; Bogoch et al., 1994) and using their measured $\delta^{18} \mathrm{O}$, the calcite-water fractionation of Friedman and O'Neil (1977) and $\delta^{18} \mathrm{O}_{\text {seawater }}=-1 \%$ SMOW (Wilson et al., 2002; Voigt et al., 2004) a sea surface temperature of 27 to $35^{\circ} \mathrm{C}$ is calculated. This temperature range broadly agrees with that estimated from pristine rudist fragments from southern Spain (Steuber et al., 2005) and other estimates for this time (Sellwood and Valdes, 2006). Therefore, oxygen isotope data is also consistent with dolomitization from seawater. 


\section{Palaeoclimatic controls on the dolomitization process}

Pervasive dolomitization from seawater on a carbonate platform can occur by temperature-controlled (geothermal) convection along the platform margin (e.g. Whitaker and Xiao, 2010) or along faults (e.g. Hollis et al., 2017), or by density-driven fluid flux of fluids downwards from brine pools located on the platform top (e.g. Whitaker et al., 2002; Garcia-Fresca et al., 2012). In the absence of evidence for syn-depositional faulting or a marked break in slope on the platform, there seems little probability of geothermal convection occurring since there would not have been sufficient temperature differentiation on the platform margin to drive fluid circulation. Furthermore, reactive transport modelling has shown that on platforms where geothermal convection does occur, density-driven reflux of seawater is a more efficient process that can dolomitize the sediment pile over a wide area (e.g. Al Helal et al., 2012).

The stratabound architecture of dolostone, as observed in the Iberian Basin, can be achieved by the reflux of evaporated seawater from brine pools that form within the peritidal zone on the platform top, driven by the increased density of the brines compared to normal seawater (Whitaker et al., 2002; Jones and Xiao, 2005; Al Helal et al., 2012). The rate of dolomitization increases with increased salinity (Gabellone and Whitaker, 2016), and therefore reflux dolomitization is commonly interpreted on platforms where there is evidence of syndepositional evaporite formation (see summary in Warren, 2000). Within the northern part of the field area, in the UZA 2.4, sedimentological data suggests that conditions were restricted and potentially above normal salinity, although there is a marked absence of sulphates, which suggests that gypsum saturation was rarely reached. This is consistent with the presence of large, Cenomanian-aged fluvial systems on the Hesperian Massif, which imply a semi-arid or humid climate (Garcia-Hidalgo et al., 2007). Easterly winds from the Atlantic Ocean, combined with elevated topography on the Hesperian Massif, could have created a rain shadow effect and a warm, dry climate in the centre of the basin (Rat, 1989). It is also possible that small scale climatic changes resulted in rapid movement of climate zones, resulting in humid-arid climatic fluctuations. In this case, the rate of evaporation might have periodically increased, raising aridity levels locally.

Overall, although it is possible that seawater within the Iberian Basin was more saline than normal seawater, and that brine pools formed within the peritidal zone, it is unlikely that they were hypersaline. Dolomitization by penesaline brines (72 to $199 \%$ ) has been interpreted in several studies (e.g. Qing et al., 2001; Bennitto and Mas, 2007; lannace et al., 2011, 2013; Rott and Qing, 2013; Newport et al., 2017) and therefore it is possible that seawater was sufficiently saline to sink and reflux through the sediment pile. Reactive transport models (RTM) demonstrate that it is possible to dolomitize large volumes of limestone by penesaline brines (Jones and Xiao, 2005; Al Helal et al., 2012; Gabellone and Whitaker, 2016), although multiple phases of fluid flux are required to cause pervasive dolomitization of the sediment stack (Garcia Fresca et al., 2009, 2012). During UZA 2.4 and 2.5T, numerous stacked, metre-scale, upward-shallowing subtidal to peritidal cycles are observed, indicating that there was an opportunity for frequent and multiple pulses of brine reflux. There is little 
evidence of intraformational aquicludes and therefore repeated flux of dolomitizing fluids could have formed dolostone bodies that coalesced to cause complete dolomitization of the platform (Figs 12 to 13). This process would have been facilitated by the migration of the brine pools during progradation of the platform, as proposed by Garcia-Fresca et al. (2012). Given the fairly thin ( $1 \mathrm{~m}$ thick) nature of each cycle, and formation of an effective intercrystalline, pore network, it is likely that each successive pulse of dolomitizing brine was able to sink further into the platform than the previous cycle.

Type iii dolomite has ${ }^{87} \mathrm{Sr} /{ }^{86} \mathrm{Sr}$ that is more radiogenic than Cenomanian seawater, and the most radiogenic samples are also enriched in Fe (Figs 9 and 10). Dolomite cement that resembles Type iii (c) is found within UZA 2.3 (Fig. 6D), suggesting that dolomite-saturated brines were transported within this formation. During migration, fluid interaction with clays within the sandstone would have enriched concentrations of radiogenic strontium and Fe within the brine, and this is reflected in the ${ }^{87} \mathrm{Sr} /{ }^{86} \mathrm{Sr}$ and Fe concentrations of the dolostone. A similar relationship between a basal clastic aquifer and pervasive dolomitization of a carbonate platform was also noted by Newport et al. (2017), suggesting that the presence of an underlying sandstone facilitated the flux of dolomitizing brines.

In UZA 2.5R, tidal flat facies are capped by karst and palaeosols, indicative of the persistence of a humid climate during the lowermost Turonian. Type $v$ dolomite, which replaces rudist shoal facies within UZA $2.5 \mathrm{R}$ in the south-east of the basin, has ${ }^{87} \mathrm{Sr} /{ }^{86} \mathrm{Sr}$ values that are higher than Cenomanian-Turonian seawater, but which resemble Campanian-Maastrichtian seawater ( 0.7079; Prokoph et al., 2008; Figure 9). Maastrichtianaged evaporites have been mapped in the Iberian Basin (Hevia and Floquet, 1982; Floquet, 1998) and if Type $v$ dolomite formed from the downward-flux of these hypersaline brines, fractionation to lighter $\delta^{18} \mathrm{O}$ could have occurred as the seawater was heated. Based on $\delta^{18} \mathrm{O}_{\text {dolomite }}=-4.3$ to $-2.8 \%$ VPDB and a $\delta^{18} \mathrm{O}_{\text {water }}=-1 \%$ o SMOW dolomitization is estimated to have occurred at 35 to $50^{\circ} \mathrm{C}$. If brines were hypersaline, then seawater would have been isotopically enriched and higher fluid temperatures $\left(>50^{\circ} \mathrm{C}\right)$ are implied. Since Upper Cretaceous sediments above UZA $2.5 \mathrm{R}$ are $\sim 500 \mathrm{~m}$ thick (Floquet, 1998) a temperature of $\sim 50^{\circ} \mathrm{C}$ could have been achieved with a geothermal gradient of $30^{\circ} \mathrm{C} / \mathrm{km}$ and a sea surface temperature of $\sim 35^{\circ} \mathrm{C}$. Type $v$ dolomite is therefore interpreted to have formed during shallow burial, from downward-circulating hypersaline Maastrichtian brines.

\section{Tectonic controls on dolomitization}

Based on facies distribution and truncation of parasequences, the carbonate platform within the study area is interpreted to have dipped southwards from the Seuil High during UZA 2.3 and 2.4 (Figs 1 and 4). It would be expected, therefore, that refluxed dolomitizing fluids would have migrated basinwards, i.e. to the south, facilitated by progradation of the platform top. This is interpreted to have caused pervasive dolomitization of the UZA 2.4 within the Iberian Basin (Fig. 12). During the lowermost Upper Cenomanian, the UZA 2.4 sequence 
boundary shows evidence of emergence (Garcia et al., 1993, Gimenez et al., 1993; Gil et al., 2004; this study) that would have reduced or terminated the supply of refluxing brines, at least on the Seuil High.

Skeletal wackestones and oolitic grainstones of UZA 2.5T conformably overly the UZA 2.4 sequence boundary across much of the basin. This is consistent with flooding of the basin as a marine connection was established between the Atlantic and Tethys Oceans (Alonso et al., 1993; Garcia-Hidalgo et al., 2007; Caus et al., 2009). At the same time, tectonic rearrangement of the Iberian Peninsula changed the Iberian Basin to a homoclinal ramp tilted from the south towards the north-west (Alonso et al., 1993; Garcia-Hidalgo et al., 2007; Caus et al., 2009). Dolomitization within UZA 2.5T is pervasive in the south, becoming partially dolomitized and disappearing completely northwards of Embid de Ariza and Ventosa, suggesting that brine pools were established in the southern part of the basin and dolomitizing brines were fluxed northwards. There was therefore a reversal of the direction of flow of dolomitizing fluids seen in the Middle Cenomanian. Northward progradation of the margin would have facilitated dolomitization through basinward migration of the brine pool across the platform top. Enrichment of ${ }^{87} \mathrm{Sr} /{ }^{86} \mathrm{Sr}$ and Fe in Type iv dolomite is also evident (Fig. 10), which could also have occurred by fluid flux via laterally equivalent or underlying sandstones with abundant clays on the Hesperian Massif (Garcia-Hidalgo et al., 2007).

Although carbonate platform growth kept pace with sea-level for much of the Upper Cenomanian, eventually, sea-level rise and global environmental change led to drowning. Across most of the basin, the uppermost Cenomanian succession comprises deep water limestone facies, although dolomitization around the Conredondo to Abenades section in the far south has obscured the stratigraphy in all but the lower part of UZA2.5 (Fig. 12). The dominance of deep water limestone within the basin indicates that the flux of dolomitizing brines was largely switched off (Fig. 13) until shallow water, normal marine conditions were restored, in the lowermost Turonian. Shelf edge rudist shoals within UZA 2.5R were then established and prograded northwards during the Lower and Middle Turonian. This basinward shift in facies led to a fully upward- shallowing succession from rudist shoals to tidal flat sediments. As these tidal flats developed, it is possible that the flux of dolomitizing fluids was re-initiated, although it is also likely that dolomitization of this succession occurred by a deeper flux of hypersaline brines in the Maastrichtian, as discussed above (Fig. 13).

\section{Post-dolomitization diagenetic modification and timing of dolomitization}

There is extensive dedolomitization within the upper UZA 2.4 on the Seuil High. On the eastern side of the Iberian Basin, beneath the top of UZA 2.4, there is an upward decrease in $\delta^{18} \mathrm{O}_{\text {dolomite }}$ and $\delta^{13} \mathrm{C}$ are more depleted than on the west side of the basin (Fig. 8). Dedolomitization has locally occurred at the top of individual parasequences, and is most pervasive in the upper $5 \mathrm{~m}$ of UZA 2.4 (Fig. 8). Here, there is a decrease in stoichiometry, increase in Ca concentration, decrease in Fe concentration and decrease in $\delta^{18} \mathrm{O}_{\text {dolomite }}$ (Figs 8 to 9). 
The top of UZA 2.4 is a third order sequence boundary that exhibits evidence of sub-aerial exposure. If dolomitization was complete by the end of UZA 2.4, then ingress of meteoric water could have recrystallized and calcitized the dolomite, resetting isotopic values and removing Fe. A slight increase in $\mathrm{Mn}$ concentration within the dedolomitized samples, compared to Type iii dolomite, suggests that Eh periodically become low enough to reduce $\mathrm{Mn}$, perhaps by stagnation of groundwater in the meteoric phreatic zone (e.g. Muchez et al., 1998). Dedolomitization was most pervasive on the Seuil High as it was emergent for longer, but also occurred locally throughout the Iberian Basin. The limitation of recrystallized, geochemically modified dolomite to the upper $5 \mathrm{~m}$ of the UZA 2.4, and occasionally parasequence tops lower in the succession, suggests that insufficient time was available for complete stabilization of the uppermost dolomite prior to platform emergence. This would have made these facies more susceptible to dedolomitization, in particular if groundwater only penetrated to a shallow depth beneath the sequence boundary. Calcite cements that occlude porosity in dedolomite and dolomitized limestone have depleted isotopic signatures, consistent with precipitation from meteoric water. Their non-luminescence reflects a low concentration of both $\mathrm{Mn}$ and Fe, which is also typical of groundwater.

The observation that calcitization occurs at this sequence boundary demonstrates that dolomitization was complete, and dedolomitization underway, prior to the onset of deposition within UZA 2.5T. UZA 2.4 lasted approximately 1 million years (Gil et al., 2004), suggesting that dolomitization of the entire UZ2.4 cycle took place in <1 million years. UZA 2.4 comprises approximately 10 upward-shallowing, metre-scale cycles, giving a depositional period of $\sim 100 \mathrm{kyr}$ per cycle. Garcia-Fresca et al. (2009) showed that over $100 \mathrm{~m}$ of sediment can be pervasively dolomitized in $2.5 \mathrm{kyr}$ based on 5 pulses of penesaline brine through a peritidal succession, assuming a reflux time of 500 years at the top of each cycle; a reflux period of 250 years caused incomplete dolomitization even with multiple pulses of fluids. Given the length of time available in the Iberian Basin to dolomitize a section that is $<20 \mathrm{~m}$ thick, this suggests that there was ample time available, and suitable fluid chemistry, during UZA 2.4 to pervasively dolomitize the entire succession.

\section{Changes in dolomite texture}

The distribution of dolomite petrotypes in the Iberian Basin is closely tied to the stratigraphic architecture of the platform. In particular, there is an upward change from distributed, finely crystalline, dolomite crystals with mottled luminescence (Types i and ii) in UZA 2.3 to pervasive, weakly fabric destructive, finely crystalline Type iii dolomite with a mottled luminescence in UZA 2.4. This is succeeded by more coarsely crystalline, zoned, fabric destructive Type iv dolomite in UZA 2.5T. UZA 2.5R is replaced by very coarsely crystalline, fabric destructive Type $v$ dolomite on the east side of the basin.

These textural changes could occur because there was a change in the volume or dolomitizing potential of the fluid from the base to the top of the UZA megacycle or they could reflect a change in the texture 
of the precursor limestone. Dolomitization in UZA 2.4 is fabric retentive in outcrop, although it is fabric destructive in thin section, suggesting there was rapid nucleation of dolomite which favoured the growth of small crystals. Both high reactive surface area and the presence of seed dolomite can be critical to ensuring pervasive, platform-scale dolomitization (Al-Helal et al., 2012; Gabellone and Whitaker, 2016), and dolomitization of UZA 2.4 could have been facilitated by its fine grained rock texture and fabric and the presence of precursor dolomite or very high magnesium calcite. In comparison, the coarser crystal size and more fabric destructive texture of Type iv and Type $v$ dolomite, could reflect higher rates of growth than nucleation, due to a lower saturation states of the dolomitising fluid or a decrease in the reactive surface area of the precursor limestone. In UZA 2.5T, this could result from a return to normal seawater salinity during relative sea-level rise. In UZA 2.5R, the dominance of rudist facies would have reduced the reactive surface area of the formation.

There is not complete conformance of petrotypes to stratigraphic boundaries, however. For example, Type iv dolomite dominates the entire UZA 2.5T on the west side of the basin, obscuring depositional facies, and potentially the Cenomanian-Turonian contact, and extending beneath the UZA2.4 sequence boundary in the far south of the study area (Llumens). Similarly Type iii dolomite is not just restricted to UZA 2.4, but has been recorded within the basal UZA 2.5T on the west side of the basin (Fig. 12). Experimental data shows that an intrinsic part of the dolomitization process is a step-wise recrystallization from very high magnesium calcite (VHMC) to calcian dolomite and then stoichiometric dolomite (Gregg et al., 2015). Therefore, when VHMC forms within shallow water carbonate sediments, it can act as a seed for subsequent dolomite growth (Machel, 2004). An alternative interpretation for the up-section change in dolomite texture, therefore is that Type i dolomite was the first phase of dolomite to form within burrows in shallow water subtidal facies, and that it was replaced by Type iii dolomite as peritidal facies became established and brine reflux was initiated during UZA 2.4. Type i dolomite might therefore only be preserved within UZA 2.3 because dolomitizing brines, that led to recrystallization to Type iii dolomite, sank beneath the basal UZA 2.4 or had lost their dolomitizing potential. This would also explain the presence of Type i and ii dolomite at the base of the UZA 2.4, above the UZA2.3 sequence boundary, at Ciria.

Similarly, Type iii dolomite could have been recrystallized to Type iv dolomite, from fluids that fluxed downwards during UZA 2.5T, in the upper Cenomanian. On the east side of the platform, the occurrence of Type $v$ dolomite could then reflect a final, localized dolomitization event from hypersaline brines, which almost completely obscured rock fabric. Since recrystallization would have resulted in a progressive increase in crystal size, porosity would have been sequentially reduced and successive phases of dolomitizing fluids would have been inhibited from flowing deeper into the platform. This would have restricted recrystallization by Type $v$ dolomite to the Turonian, particularly since the underlying uppermost Cenomanian mudstone would have acted as an aquiclude. Similarly, Type iv dolomite is largely restricted to UZA 2.5T, and only in the most proximal part of the platform does it extend into UZA 2.4 (at Llumens; Fig. 12). In this case the change in dolomite 
texture up-section is effectively a fossilized dolomitization reaction front, whereby the earliest phases of dolomitization are only preserved in the oldest strata because changes in pore structure during successive phases of dolomitization, as well as thickening of the sediment pile with ongoing carbonate platform growth, prevent recrystallization by reflux of younger dolomitizing brines.

\section{CONCLUSIONS AND IMPLICATIONS}

Based on petrographical, field and geochemical data of dolomitized strata in the Iberian Basin, the following conclusions can be drawn:

- Dolomitization of Cenomanian platform limestones of the Iberian Basin took place from penesaline, penecontemporaneous brines during the Middle and Upper Cenomanian. Dolomitization of Turonian sediments apparently occurred from younger (Campanian-Maastrichtian), hypersaline seawater during shallow burial $(<500 \mathrm{~m})$.

- Dolomitization appears to have been initiated in burrows within subtidal facies, with localized, finely crystalline Type (i) replacive dolomite and Type ii dolomite cement. Dolomitization is most pervasive within UZA 2.4, which is pervasively replaced by finely crystalline Type iii dolomite. It is interpreted to have formed from seawater that refluxed from brine pools formed within peritidal facies, during $<100$ ky depositional cycles. It is likely that dolomitization was facilitated by the fine grain size of the sediment and nucleation upon precursor Type i dolomite within burrows. An underlying clastic succession potentially acted as an aquifer, permitting flux of dolomitizing fluids further into the basin.

- Dolomitization of UZA 2.4 was complete in $<1 \mathrm{My}$. At the top of the formation, infiltration of meteoric water during platform emergence led to localized recrystallization and resetting of geochemical fingerprints within the top few metres of the formation, evidenced by depleted $\delta^{18} \mathrm{O}$ and $\mathrm{Fe}$ concentrations, prior to UZA 2.5 .

- Reorganization of microplates during the middle Cenomanian led to a reversal of ramp polarity, and hence the direction of fluid flow of refluxing brines changed from north to south to south to north, so that that changes in the arrangement of the basin topography had a major effect on the hydrology of the basin.

- Dolomitization was terminated across most of the platform by relative sea-level rise and oceanic acidification in the late Cenomanian. With a fall in relative sea-level in the Turonian, a rudist-dominated, shallow marine carbonate platform was established. It prograded from south to north and is pervasively dolomitized by hypersaline, Maastrichtian brines. Enriched $\delta^{13} \mathrm{C}$ within the basal UZA 2.5R suggests that isotopic evidence of global changes in seawater chemistry might be preserved within sediments that have subsequently been dolomitized. 
- There is an up-section increase in dolomite crystal size that might reflect differences in the reactive surface area and, potentially, the potency of the dolomitizing fluid, between stratigraphic layers. However, the incomplete stratigraphic conformance of dolomite petrotypes also suggests that the change in crystallinity could reflect recrystallization to coarser, stable dolomite during successive fluxes of dolomitizing brine, such that the Types $i$ to $v$ dolomite effectively preserve the paragenetic evolution of dolomitization on the Iberian Platform.

\section{ACKNOWLEDGEMENTS}

This forms part of the PhD thesis of Richard Newport, who was funded by the North Africa Research Group at University of Manchester, sponsored by Hess, Anadarko, BG, Wintershall, Repsol, RWE, Dana, BP, Cairn, Chevron, Kosmos and Conoco-Phillips. Strontium isotope analysis was carried out at the University of the Basque Country. Carbon and oxygen isotopic analysis and major, minor and trace element geochemistry was conducted at the Ruhr University, Bochum and all other geochemical analysis was undertaken at the Williamson Resource Centre, University of Manchester. We would like to thank Javier Gil for very valuable discussions during preparation of this manuscript. We also thank Associate Editor Jody Webster, Beatriz Garcia-Fresca and two anonymous reviewers for their comments that significantly improved an earlier version of this manuscript.

\section{REFERENCES}

Adams, J. E. \& Rhodes, M. L. 1960. Dolomitization by seepage refluxion. AAPG Bulletin, 44, 1912-1920.

Al-Helal, A. B., Whitaker, F. F. \& Xiao, Y. 2012. Reactive transport modeling of brine reflux: dolomitization, anhydrite precipitation, and porosity evolution. Journal of Sedimentary Research, 82, 196-215.

Alonso, A., Floquet, M., Mas, R. \& Meléndez, A. 1993. Late Cretaceous carbonate platforms: origin and evolution, Iberian Range, Spain. Memoirs-American Association of Petroleum Geologists, 297-297.

Banner, J., Hanson, G and Meyer, W., 1988. Rare Earth Element and Nd Isotopic Variation in Regionally Extensive Dolomites from the Burlington-Keokuk Trend: Implications for REE Mobility During Carbonate Diagenesis. Journal of Sedimentary Petrology, 58, 415-432

Benito, M. \& Mas, R. 2007. Origin of Late Cretaceous dolomites at the southern margin of the Central System, Madrid Province, Spain. Journal of Iberian geology, 33, 41-54.

Bogoch, R., Buchbinder, B. \& Magaritz, M. 1994. Sedimentology and geochemistry of lowstand peritidal lithofacies at the Cenomanian-Turonian boundary in the Cretaceous carbonate platform of Israel. Journal of Sedimentary Research, 64, 733-740. 
Bontognali, T. R., Vasconcelos, C., Warthmann, R. J., Bernasconi, S. M., Dupraz, C., Strohmenger, C. J. \& Mckenzie, J. A. 2010. Dolomite formation within microbial mats in the coastal sabkha of Abu Dhabi (United Arab Emirates). Sedimentology, 57, 824-844.

Caus, E., Bernaus, J., Calonge, E. \& Martín-Chivelet, J. 2009. Mid-Cenomanian separation of Atlantic and Tethyan domains in Iberia by a land-bridge: The origin of larger foraminifera provinces? Palaeogeography, Palaeoclimatology, Palaeoecology, 283, 172-181.

Chumakov, N., Zharkov, M., Herman, A., Doludenko, M., Kalandadze, N., Lebedev, E., Ponomarenko, A. \& Rautian, A. 1995. Climatic belts of the Mid-Cretaceous. Stratigraphy and Geological Correlation, 3, 241-260.

Corlett, $\mathrm{H}$ and Jones, B., 2012. Petrographic and geochemical contrasts between calcite and dolomite filled burrows in the Middle Devonian Lonely Bay Formation, Northwest Territories, Canada: implications for dolomite formation in Palaeozoic burrows. Journal of Sedimentary Research, 82, 648-663, doi: 10.2110/jsr.2012.12.57

Dickson, J. 1966. Carbonate identification and genesis as revealed by staining. Journal of Sedimentary Research, 36, 491-505.

Floquet, M. 1991. La Plate-form Nord-Castillane au Cretace Superieur (Espagne). PhD, Universite de Dijon, pp 1926.

Floquet, M. 1998. Outcrop cycle stratigraphy of shallow ramp deposits: the Late Cretaceous series on the Castillian Ramp (Northern Spain), SEPM special publication, 60, 1-19.

Friedman, I. \& O'neil, J. R. 1977. Compilation of stable isotope fractionation factors of geochemical interest, In: Fleischer, M. (Ed.) Data of geochemistry, USGS professor paper, 440-KK.

Gabellone, T And Whitaker, F., 2016. Secular variations in seawater chemistry controlling dolomitzation in shallow reflux systems: insights from reactive transport modelling. Sedimentology, 63, 1233-1259

Garcia-Fresca, B., Jones, G. D. \& Xu, T. 2009. The apparent stratigraphic concordance of reflux dolomite: new insights from synsedimentary reactive transport models. AAPG Search and Discovery Article, 50208.

Garcia-Fresca, B., Lucia, F.J., Sharp, J.M and Kerans, C. (2012). Outcrop-constrained hydrogeological simulations of brine reflux and early dolomitization of the Permian San Andreas Formation. AAPG Bulletin, 96, 1757-1781. García, A., Segura, M., García-Hidalgo, J. \& Carenas, B. 1993. Mixed siliciclastic and carbonate platform of AlbianCenomanian age from the Iberian Basin, Spain. Memoirs - American Assocaition of Petroleum Geologists, 255255.

García-Mondéjar, J. 1996. Plate reconstruction of the Bay of Biscay. Geology, 24, 635-638.

García, A., Segura, M. \& García-Hidalgo, J. 1996. Sequences, cycles and hiatuses in the Upper Albian-Cenomanian of the Iberian Ranges (Spain): a cyclostratigraphic approach. Sedimentary Geology, 103, 175-200. 
Garcia-Hidalgo, J. F., Gil, J., Segura, M. \& Domínguez, C. 2007. Internal anatomy of a mixed siliciclastic-carbonate platform: the Late Cenomanian-Mid Turonian at the southern margin of the Spanish Central System. Sedimentology, 54, 1245-1271.

Gil, J., Carenas, B., Hidalgo, J. G., Segura, M. \& García, A. 2004. Unidades litoestratigráficas del Cretácico superior en el centro de España. Revista de la Sociedad Geológica de España, 17, 249-266.

Gil, J., García-Hidalgo, J., Segura, M., García, A. \& Carenas, B. 2006. Stratigraphic architecture, palaeogeography and sea-level changes of a third order depositional sequence: the Late Turonian-Early Coniacian in the northern Iberian Ranges and Central System (Spain). Sedimentary Geology, 191, 191-225.

Giménez, R., Martín-Chivelet, J. \& Vilas, L. 1993. Late Albian-Middle Cenomanian Carbonate Platforms of Betic and Iberian Basins, Spain. Memoirs - American Assocaition of Petroleum Geologists, 271-271.

Given, R. K. \& Wilkinson, B. H. 1987. Dolomite abundance and stratigraphic age; constraints on rates and mechanisms of Phanerozoic dolostone formation. Journal of Sedimentary Research, 57, 1068-1078.

Gregg, J. M., Howard, S. A. \& Mazzullo, S. 1992. Early diagenetic recrystallization of Holocene (<3000 years old) peritidal dolomites, Ambergris Cay, Belize. Sedimentology, 39, 143-160.

Gregg, J., Bish, D., Kaczmarek, S and Machel, H., 2015. Mineralogy, nucleation and growth of dolomite the laboratory and sedimentary environment: A review. Sedimentology, 62, 1749-1769

Haq, B. U., Hardenbol, J. \& Vail, P. R. 1987. Chronology of fluctuating sea levels since the Triassic. Science, 235, 1156-1167.

Hevia, A. M. \& Floquet, M. 1982. Características sedimentarias y paleogeográficas de la regresión finicretácica en el sector central de la Cordillera Ibérica. Cuadernos de geología ibérica, 237-258.

Hollis, C., Bastesen, E., Boyce, A., Corlett, H., Gawthorpe, R., Hirani, J., Rotevatn, A and Whitaker, F, 2017. Fault controlled dolomitization in a rift basin. Geology, 45, 219-222 doi:10.1130/G38394.1lannace, A., Capuano, M. \& Galluccio, L. 2011. "Dolomites and dolomites" in Mesozoic platform carbonates of the Southern Apennines: Geometric distribution, petrography and geochemistry. Palaeogeography, Palaeoclimatology, Palaeoecology, 310, 324-339.

lannace, A., Frijia, G., Galluccio, L. \& Parente, M. 2013. Facies and early dolomitization in Upper Albian shallowwater carbonates of the southern Apennines (Italy): paleotectonic and paleoclimatic implications. Facies, 60.1 $1-26$.

Jenkyns, H.C., 2010, Geochemistry of Oceanic Anoxic Events: Geochemistry Geophysics, Geosystems, 11, Q03004, doi: 10.1029/2009GC002788. 
Jones, G. D. \& Xiao, Y. 2005. Dolomitization, anhydrite cementation, and porosity evolution in a reflux system: Insights from reactive transport models. AAPG Bulletin, 89, 577-601.

Korbar, T., Glumac, B., Tesovic, B.C. and Cadieux, S., 2012. Response of a carbonate platform to the CenomanianTuronian drowning and OAE 2: a case study from the Adriatic Platform (Dalmatia, Croatia). Journal of Sedimentary Research, 82, 163-176

Lumsden, D. N. 1979. Discrepancy between thin-section and X-ray estimates of dolomite in limestone. Journal of Sedimentary Research, 49, 429-435.

Machel, H. G. 2004. Concepts and models of dolomitization: a critical reappraisal. In: Braithwaite, C. J. R., Rizzi, G. \& Darke, G. (Eds.) The geometry and petrogenesis of dolomite hydrocarbon reservoirs:The geometry and petrogenesis of dolomite hydrocarbon reservoirs: Geological Society (London) Special Publication, 235, 7-63.

Martin-Chivelet, J. 1995. Sequence stratigraphy of mixed carbonate-siliciclastic platforms developed in a tectonically active setting, Upper Cretaceous, Betic continental margin (Spain). Journal of Sedimentary Research, $65,235-254$.

Matthews, A And Katz, A (1977) Oxygen isotope fractionation during the dolomitization of calcium carbonate. Geochimica et Cosmochimica Acta, 41, 1431-1438

Mazzullo, S. 2000. Organogenic dolomitization in peritidal to deep-sea sediments. Journal of Sedimentary Research, 70, 10-23.

Mcarthur, J., Howarth, R. \& Bailey, T. 2001. Strontium isotope stratigraphy: LOWESS version 3: best fit to the marine Sr-isotope curve for 0-509 Ma and accompanying look-up table for deriving numerical age. The Journal of Geology, 109, 155-170.

Montanez, I. P. \& Read, J. F. 1992a. Fluid-rock interaction history during stabilization of early dolomites, upper Knox Group (Lower Ordovician), US Appalachians. Journal of Sedimentary Research, 62, 753-778.

Montanez, I. P. \& Read, J. F. 1992b. Eustatic control on early dolomitization of cyclic peritidal carbonates: Evidence from the Early Ordovician Upper Knox Group, Appalachians. Geological Society of America Bulletin, $104,872-886$.

Muchez, P., Nielsen, P., Sintubin, M. \& Lagrou, D. 1998. Conditions of meteoric calcite formation along a Variscan fault and their possible relation to climatic evolution during the Jurassic-Cretaceous. Sedimentology, 45, 845854.

Newport, R., Hollis, C., Segura, M., Bodin, S. \& Redfern, J. 2013. Controls on dolomitisation of Cenomanian neritic carbonates of the central Iberian Basin, Spain. In: GARCíA-HIDALGO, J. F., (ed.) V Congresso del Cretacio de Espana, 8/07-2013-11/07/2013 2013 Guadalajara. 
Newport, R. 2014. Dolomitisation of Cenomanian-Turonian Carbonates, North Africa and Western Mediterranean. Unpublished PhD, University of Manchester.

Newport, R., Hollis, C., Bodin, S. and Redfern, J., 2017, Examining the interplay of climate and low amplitude sealevel change on the distribution and volume of massive dolomitisation: Zebbag Formation, Cretaceous, Southern Tunisia, Depositional Record, doi: 10.1002/dep2.25

Peyrot, D., Barroso-Barcenilla, F., Barrón, E. \& Comas-Rengifo, M. J. 2011. Palaeoenvironmental analysis of Cenomanian-Turonian dinocyst assemblages from the Castilian Platform (Northern-Central Spain). Cretaceous Research, 32, 504-526.

Pin, C. \& Bassin, C. 1992. Evaluation of a strontium-specific extraction chromatographic method for isotopic analysis in geological materials. Analytica Chimica Acta, 269, 249-255.

Pin, C., Briot, D., Bassin, C. \& Poitrasson, F. 1994. Concomitant separation of strontium and samariumneodymium for isotopic analysis in silicate samples, based on specific extraction chromatography. Analytica Chimica Acta, 298, 209-217.

Platzman, E. \& Lowrie, W. 1992. Paleomagnetic evidence for rotation of the Iberian Peninsula and the external Betic Cordillera, Southern Spain. Earth and Planetary Science Letters, 108, 45-60.

Poulsen, C. J., Seidov, D., Barron, E. J. \& Peterson, W. H. 1998. The impact of paleogeographic evolution on the surface oceanic circulation and the marine environment within the Mid-Cretaceous tethys. Paleoceanography, 13, 546-559.

Qing, H., Bosence, D. W. \& Rose, E. P. 2001. Dolomitization by penesaline sea water in Early Jurassic peritidal platform carbonates, Gibraltar, western Mediterranean. Sedimentology, 48, 153-163.

Rat, P. 1989. The Iberian Cretaceous: climatic implications. In: Cretaceous of the Western Tethys: Proceedings of the Third International Cretaceous Symposium, Tubingen, E. Schweizerbartsche Verlagsbuchhanndlung, Stuttgart, 1989. 17-25.

Rodríguez-López, J., De Boer, P., Meléndez, N., Soria, A. \& Pardo, G. 2006. Windblown desert sands in coeval shallow marine deposits: a key for the recognition of coastal ergs in the mid-Cretaceous Iberian Basin, Spain. Terra Nova, 18, 314-320.

Rodriguez-Lopez, J. P., Melendez, N., De Boer, P. L. \& Soria, A. R. 2008. Aeolian sand sea development along the mid-Cretaceous western Tethyan margin (Spain): erg sedimentology and palaeoclimate implications. Sedimentology, 55, 1253-1292. 
Rott, C. M. \& Qing, H. 2013. Early Dolomitization and Recrystallization in Shallow Marine Carbonates, Mississippian Alida Beds, Williston Basin (Canada): Evidence from Petrography and Isotope Geochemistry. Journal of Sedimentary Research, 83, 928-941.

Scholle, P. A. \& Arthur, M. A. 1980. Carbon isotope fluctuations in Cretaceous pelagic limestones: potential stratigraphic and petroleum exploration tool. AAPG Bulletin, 64, 67-87.

Schouten, S., Hopmans, E. C., Forster, A., Van Breugel, Y., Kuypers, M. M. \& Damsté, J. S. S. 2003. Extremely high sea-surface temperatures at low latitudes during the middle Cretaceous as revealed by archaeal membrane lipids. Geology, 31, 1069-1072.

Segura, M. \& García, A. 1985. La transgresión cenomanense en el sector septentrional de la" Serranía de Cuenca"(provincias de Cuenca y Guadalajara, Cordillera Ibérica). Acta geológica hispánica, 20, 209-217.

Segura, M., García-Hidalgo, J., Carenas, B. \& García, A. 1993a. Late Cenomanian-early Turonian platform from central eastern Iberia, Spain. Memoirs-American Association of Petroleum Geologists, 283-283.

Segura, M., Garcia, A., Garcia-Hidalgo, J. \& Carenas, B. 1993b. The Cenomanian-Turonian transgression in the Iberian Ranges (Spain): depositional sequences and the location of the Cenomanian-Turonian boundary. Cretaceous Research, 14, 519-529.

Sellwood, B. W. \& Valdes, P. J. 2006. Mesozoic climates: General circulation models and the rock record. Sedimentary Geology, 190, 269-287.

Sibley, D. F. \& Gregg, J. M. 1987. Classification of Dolomite Rock Textures. Journal of Sedimentary Petrology, 57, 967-975.

Smith, T. M. \& Dorobek, S. L. 1993. Alteration of early-formed dolomite during shallow to deep burial: Mississippian Mission Canyon Formation, central to southwestern Montana. Geological Society of America Bulletin, 105, 1389-1399.

Stanley, S. M. \& Hardie, L. A. 1998. Secular oscillations in the carbonate mineralogy of reef-building and sediment-producing organisms driven by tectonically forced shifts in seawater chemistry. Palaeogeography, Palaeoclimatology, Palaeoecology, 144, 3-19.

Steiger, R. H. \& Jäger, E. 1977. Subcommission on geochronology: convention on the use of decay constants in geo-and cosmochronology. Earth and Planetary Science Letters, 36, 359-362.

Steuber, T., Rauch, M., Masse, J.-P., Graaf, J. \& Malkoč, M. 2005. Low-latitude seasonality of Cretaceous temperatures in warm and cold episodes. Nature, 437, 1341-1344.

Sun, S. Q. 1994. A reappraisal of dolomite abundance and occurrence in the Phanerozoic. Journal of Sedimentary Research, 64, 396-404. 
Van Wees, J., Arche, A., Beijdorff, C., López-Gómez, J. \& Cloetingh, S. A. 1998. Temporal and spatial variations in tectonic subsidence in the Iberian Basin (eastern Spain): inferences from automated forward modelling of highresolution stratigraphy (Permian-Mesozoic). Tectonophysics, 300, 285-310.

Voigt, S., Gale, A. S. \& Flögel, S. 2004. Midlatitude shelf seas in the Cenomanian-Turonian greenhouse world: Temperature evolution and North Atlantic circulation. Paleoceanography, 19, PA4020.

Warren, J. 2000. Dolomite: occurrence, evolution and economically important associations. Earth-Science Reviews, 52, 1-81.

Whitaker, F. F., Smart, P. L. \& Jones, G. D. 2004. Dolomitization: from conceptual to numerical models. The geometry and petrogenesis of dolomite hydrocarbon reservoirs: Geological Society (London) Special Publication, 235, 99-139

Whitaker, F and Xiao, Y., 2010. Reactive transport modeling of early burial dolomitization of carbonate platforms by geothermal convection. AAPG Bulletin, 94, 889-917

Wiedmann, J. 1975. Subdivisiones y precisiones bio-estratigráficas en el Cretácico Superior de las Cadenas Celtibéricas. In: Actas 1er Symposium sobre el Cretácico de la Cordillera Ibérica, Cuenca, 1975. 135-153.

Wilmsen, M. 2000. Evolution and demise of a mid-Cretaceous carbonate shelf: the Altamira Limestones (Cenomanian) of northern Cantabria (Spain). Sedimentary Geology, 133, 195-226.

Wilson, P. A. \& Norris, R. D. 2001. Warm tropical ocean surface and global anoxia during the mid-Cretaceous period. Nature, $412,425-429$.

Wilson, P. A., Norris, R. D. \& Cooper, M. J. 2002. Testing the Cretaceous greenhouse hypothesis using glassy foraminiferal calcite from the core of the Turonian tropics on Demerara Rise. Geology, 30, 607-610.

\section{Figure Captions}

Fig. 1. Palaeogeographical map of the Iberian Peninsula during the middle Cenomanian. Adapted from Torices et al. (2012) with wind direction taken from Poulsen et al, (1998) showing field area (dotted red square) that is presented in detail in Fig. 2. Dashed black line represents outline of modern day Spanish and French coastline.

Fig. 2. Location map showing the location of the field area in Spain and location of logged sections in the field area, with dashed white lines marking correlations shown in Fig. 4 (eastern section = Fig. 4A; western section = Fig. 4B). The map also shows the location of Hesperian Massif and Seuil High (Floquet, 1991).

Fig. 3 Stratigraphic columns showing the formations of the Upper Albian to lower Turonian of the northern part of the Iberian Basin based on Segura et al. (1993). Formation names and dating of cycles based on data from Gil et al. (2004). Lithology based on this study. 
Fig. 4. Sedimentological cross sections across the Iberian Basin. (A) Eastern cross section, and (B) western cross section as shown in Fig 2. The Cenomanian-Turonian boundary (top UZA 2.5R) is observed in the eastern section, but not in the western section (not exposed)

Fig. 5 .Photomicrographs showing (A) plane polarized light (PPL) photomicrograph of type (i) dolomite and (B) detail of box shown in (A). (C) PPL image showing planar-p dolomite within a micrite matrix and (D) same image as in (C) but taken under CL. (E) PPL image showing dolomite cement type (ii) partially filling vuggy porosity (red outline). (F) Type (ii) cement (white outline) filling a mouldic pore (red outline) under $\mathrm{CL}$

Fig. 6. Photomicrographs showing (A) type (iii a) dolomite under PPL. (B) Same image as in (A) but taken under $\mathrm{CL}$. (C) Type (iii b) replacive dolomite overprinting finer crystalline dolomite showing rare cloudy core, clear rim morphology and (D) type (iii C) dolomite. (E) shows same image as (D) but taken under CL. Abbreviations: cccalcite cement, $\mathrm{dc}$ - dolomite cement and $\mathrm{dr}$ - dolomite replacement

Fig. 7. Carbon and oxygen isotope cross plot showing the isotopic signature for dolomite petrotypes within the Iberian Range. Black box represents marine limestone signature based on isotopic analysis from lateral equivalent strata. Black box marks approximate isotopic range of marine calcite; grey box represents marine dolomite signature based on a $+3.00 \%$ enrichment compared to penecontemporaneous limestone (Budd, 1997)

Fig. 8. Depth plots showing the change in (A)average crystal size, (B) percent calcite (C) carbon isotope ratios (D) oxygen isotope ratios and $(E)$ concentration of iron within Cenomanian-Turonian strata of the Iberian Basin. Plots are datumed to top UZA2.4. The pale grey horizontal band within UZA2.5 marks the interpreted position of OAE2.

Fig. 9. (A) $\delta^{18} \mathrm{O}$ and Fe concentration for type (iii) dolomite and (B) Ca and $\delta^{18} \mathrm{O}$. based on location within the basin.

Fig. 10 Covariance plots showing the change in (A) $\delta^{18} \mathrm{O}$, (B) Sr concentration, (C) Fe concentration and (D) Mn concentration, (against ${ }^{87} \mathrm{Sr} /{ }^{86} \mathrm{Sr}$ isotope ratios for all dolomite types. Blue shading shows approximate range of ${ }^{87} \mathrm{Sr} /{ }^{86} \mathrm{Sr}_{\text {seawater }}$ from Cenomanian- Turonian ( 0.7075) to Maastrichtian seawater ( 0.7079) (from Prokoph et al., 2008).

Fig. 11. Type iv (a) dolomite showing cloudy core, clear rim morphology under (A) PPL and (B) cross polarized light (XPL). Type (v) dolomite under (C) PPL and (D) CL. Abbreviations: $c c$ - meteoric calcite cement, dr dolomite replacement.

Fig. 12 Distribution of dolomite in cross section across the Iberian Basin; (A) western cross section, and (B) eastern cross section as shown in Fig. 2. The Cenomanian-Turonian boundary (top UZA 2.5R) is observed in the eastern section, but not in the western section (not exposed) 
Fig. 13 Conceptual model showing dolomitization during the Cenomanian and Turonian. Map and cross section on right hand side of figure refers to palaegeographical arrangement of the Iberian Peninsula during the Upper Cretaceous. Palaeogeographical maps adapted from Alonso et al., (1993). (A) Formation of brine pools on the platform top within the northern Iberian Basin fluxed southwards during the middle Cenomanian. Dolomite nucleated upon Type (i) and (ii) dolomite within subtidal facies. The underlying sandstones of the UZA2.2 (Lower Cenomanian) potentially facilitated the basinward flux of brines. Following platform emergence (B), plate reorganization led to flooding of the basin and a northward-dipping ramp was established (C) abd dolomitizing brines fluxed northwards from peritidal brine pools in the south of the study area in the Upper Cenomanian. (D) sea-level rise and ocean acidification reduced carbonate productivity and an increase in water depth cut off the supply of dolomitizing fluids. (E) An increase in carbonate productivity and a re-established shallow water carbonate platform meant dolomitization from northwards-fluxing brines was initiated again in the Turonian (F), dolomitization potentially continued during the Campanian to Maastrichtian, when dense saline brine pools were established during desiccation and precipitation of evaporites.

Table 1. GPS co-ordinates for logged sections

Table 2. Petrographical properties of dolomite petrotypes

Table 3. Summary of geochemical properties of dolomite petrotypes. Note types (i) and (ii) could not be sampled. 
Figure 1

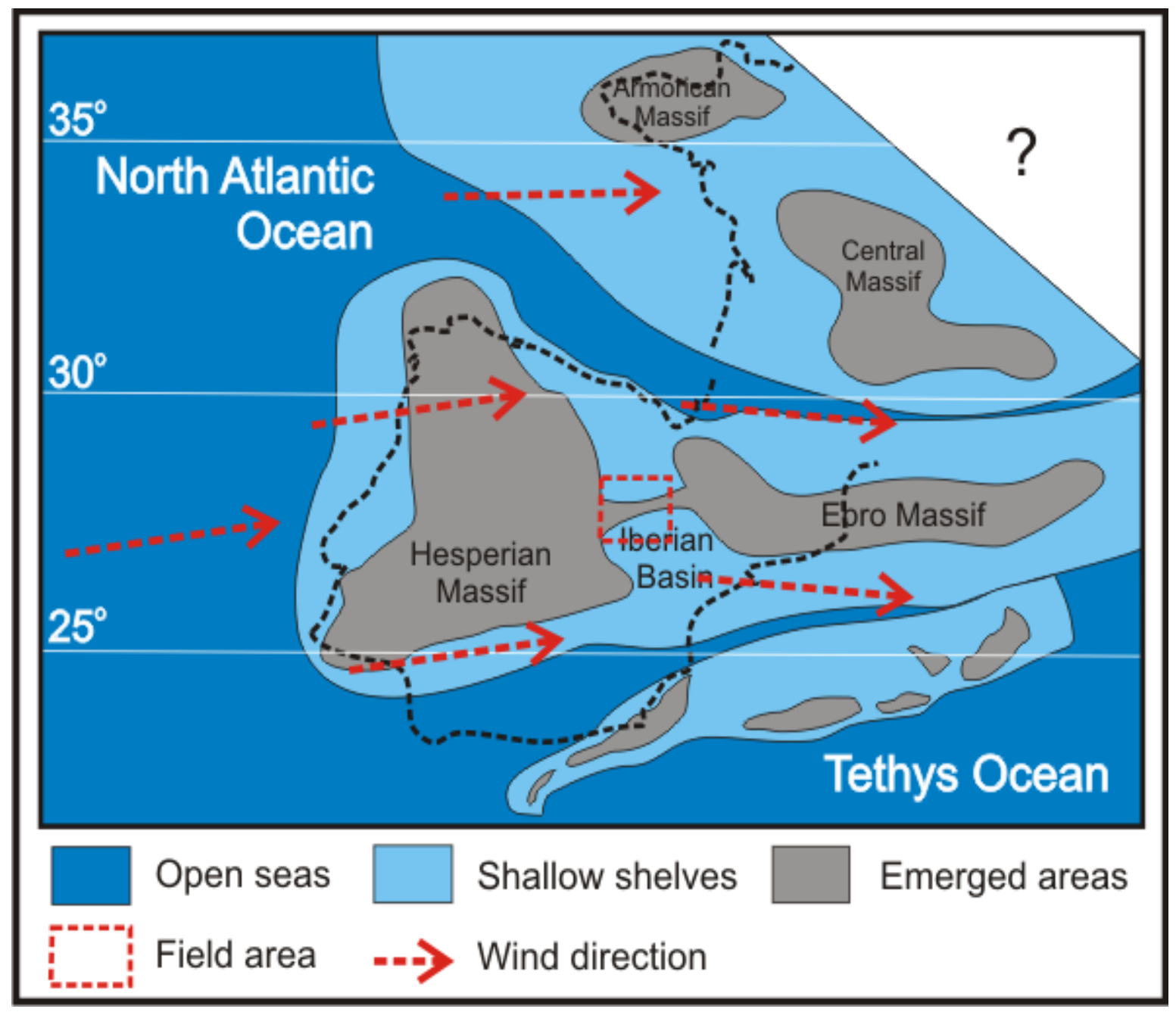


Figure 2

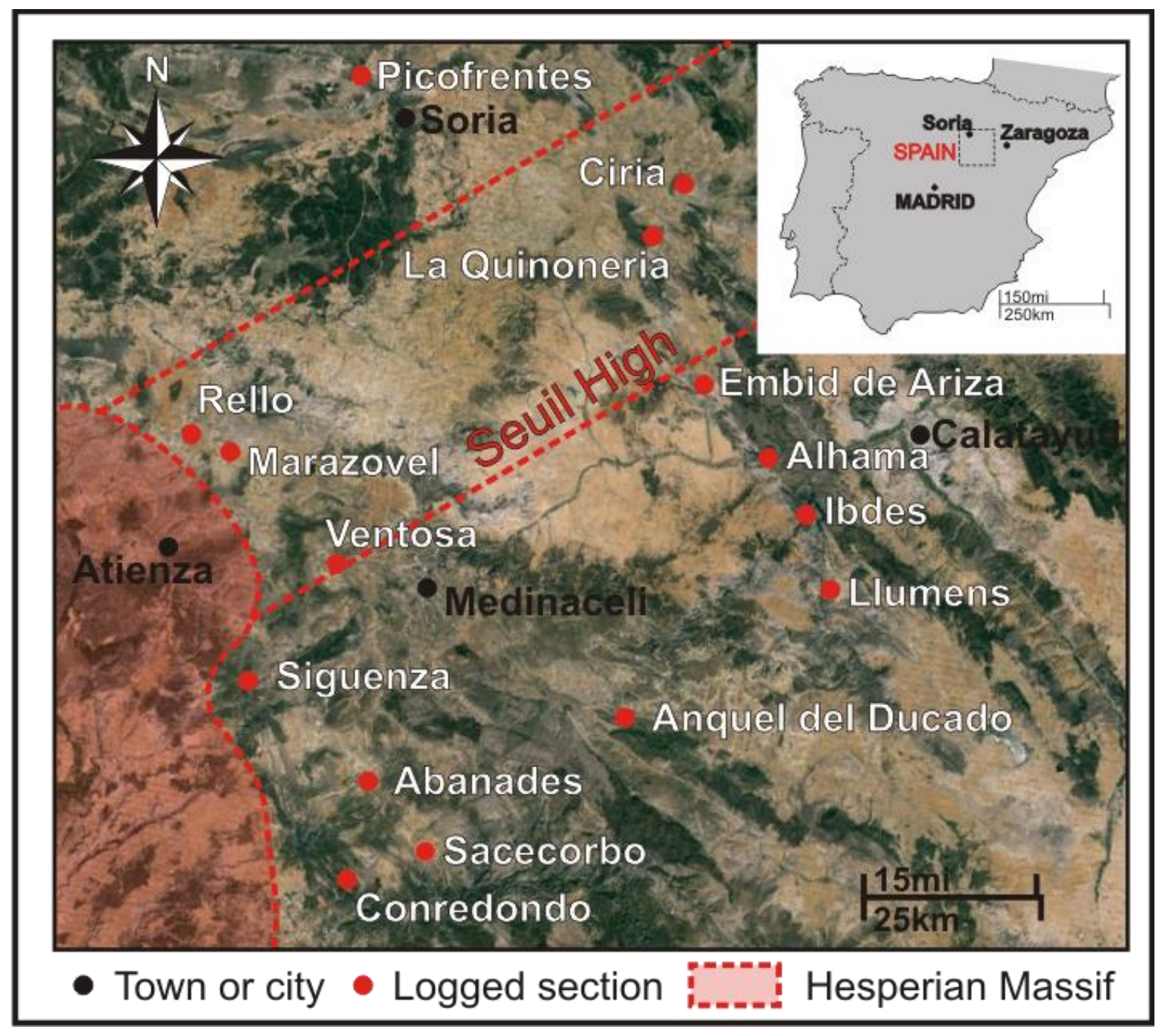


Figure 3
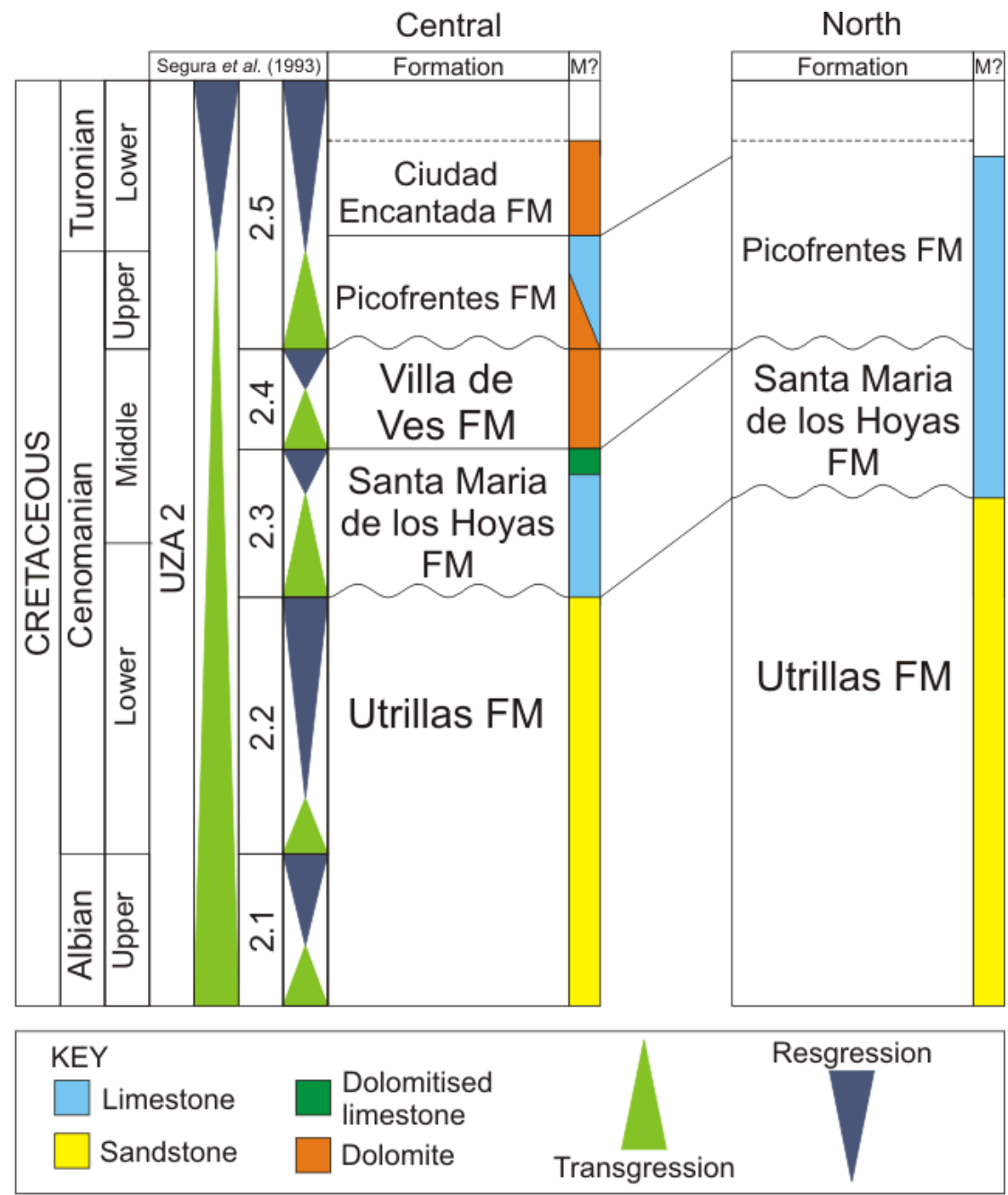
Figure 4
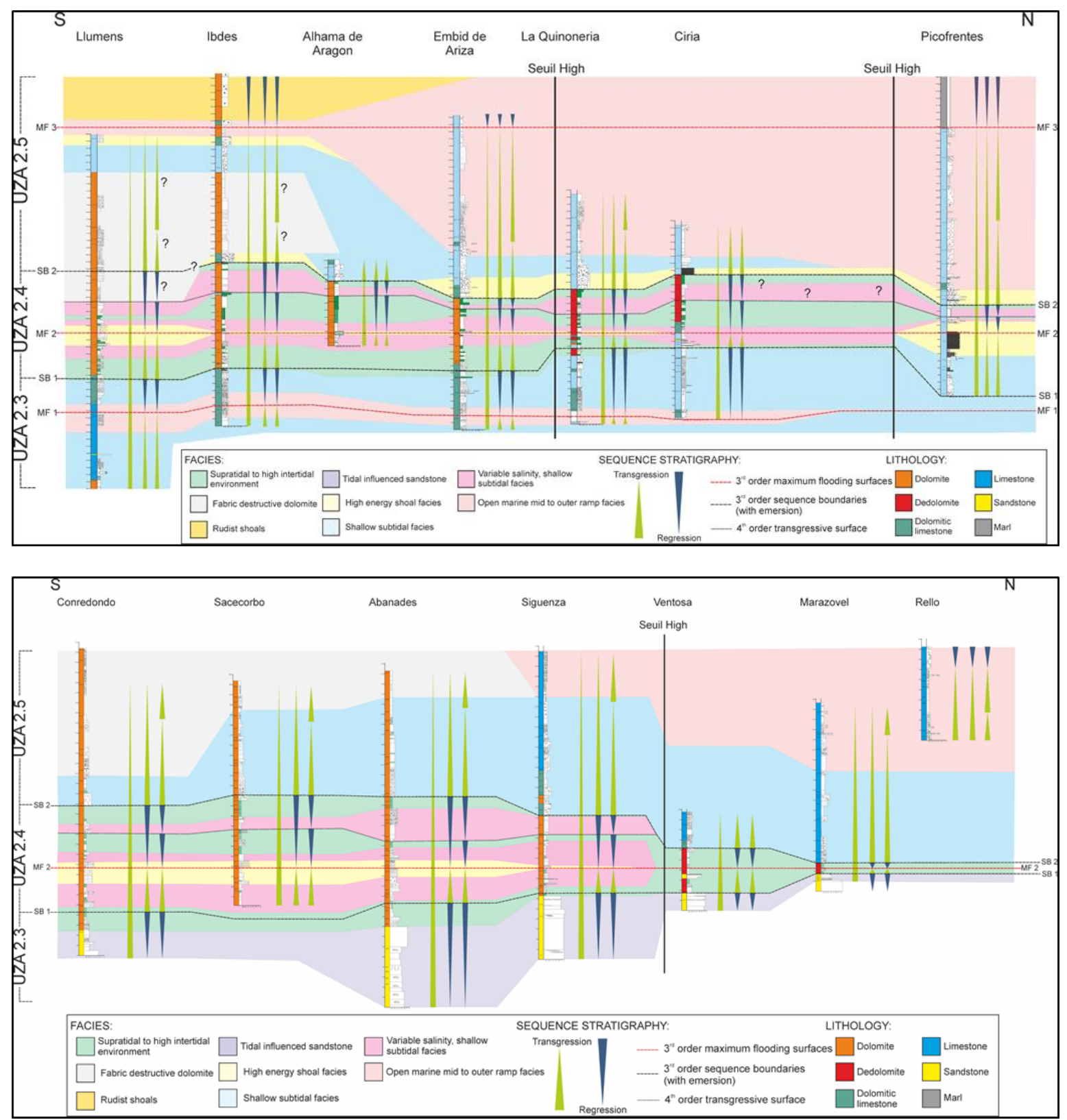
Figure 5
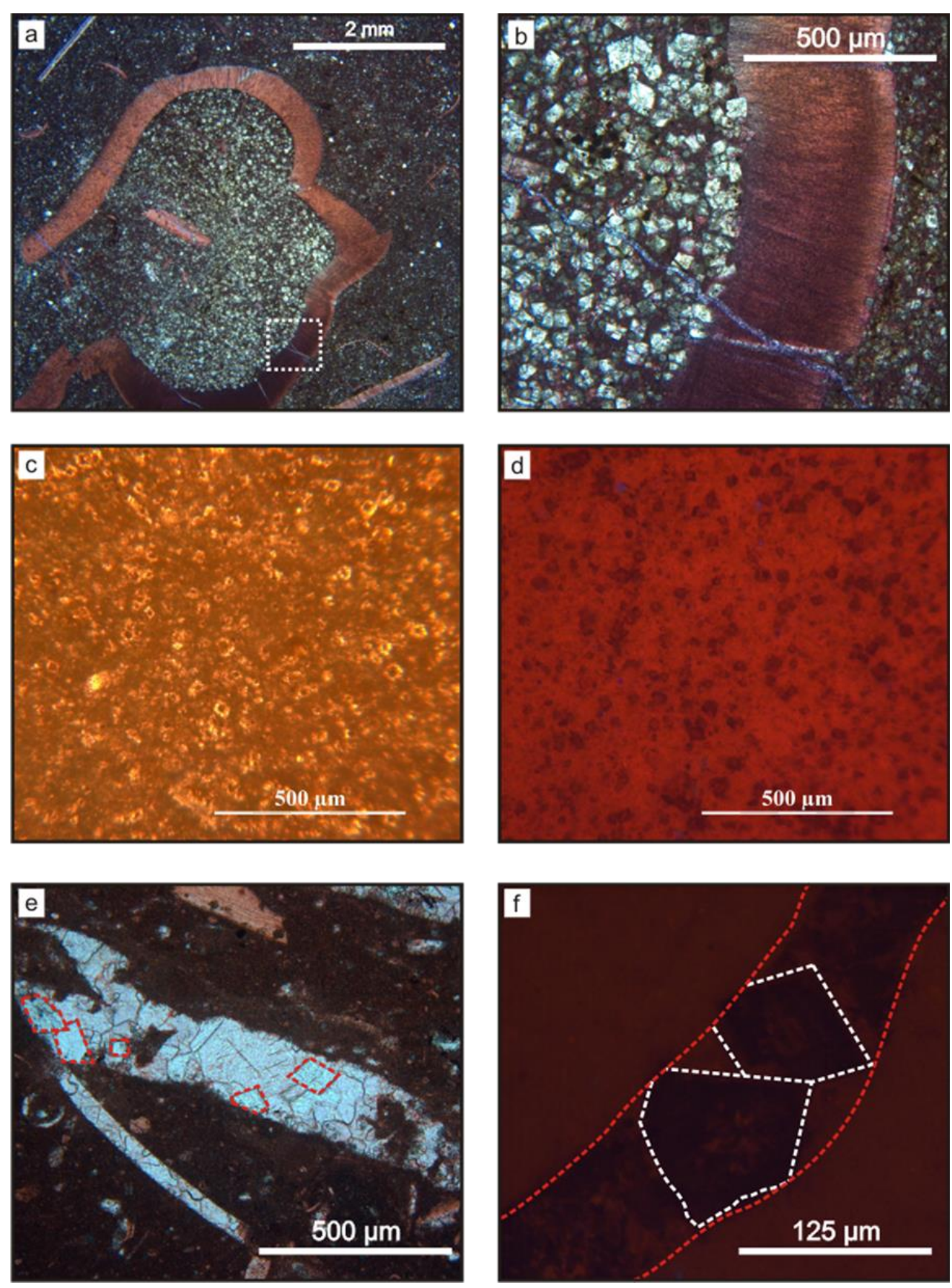
Figure 6
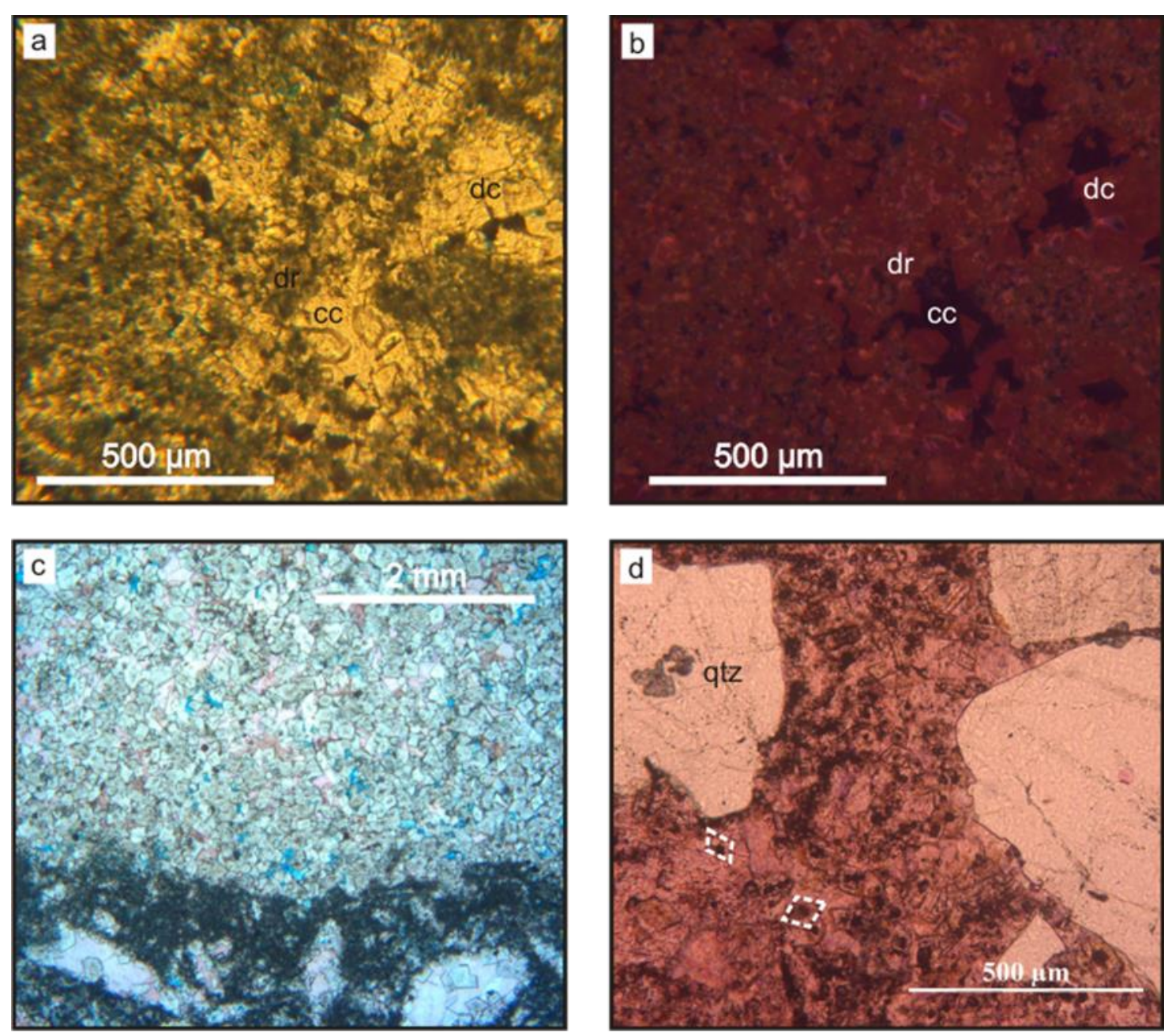
Figure 7

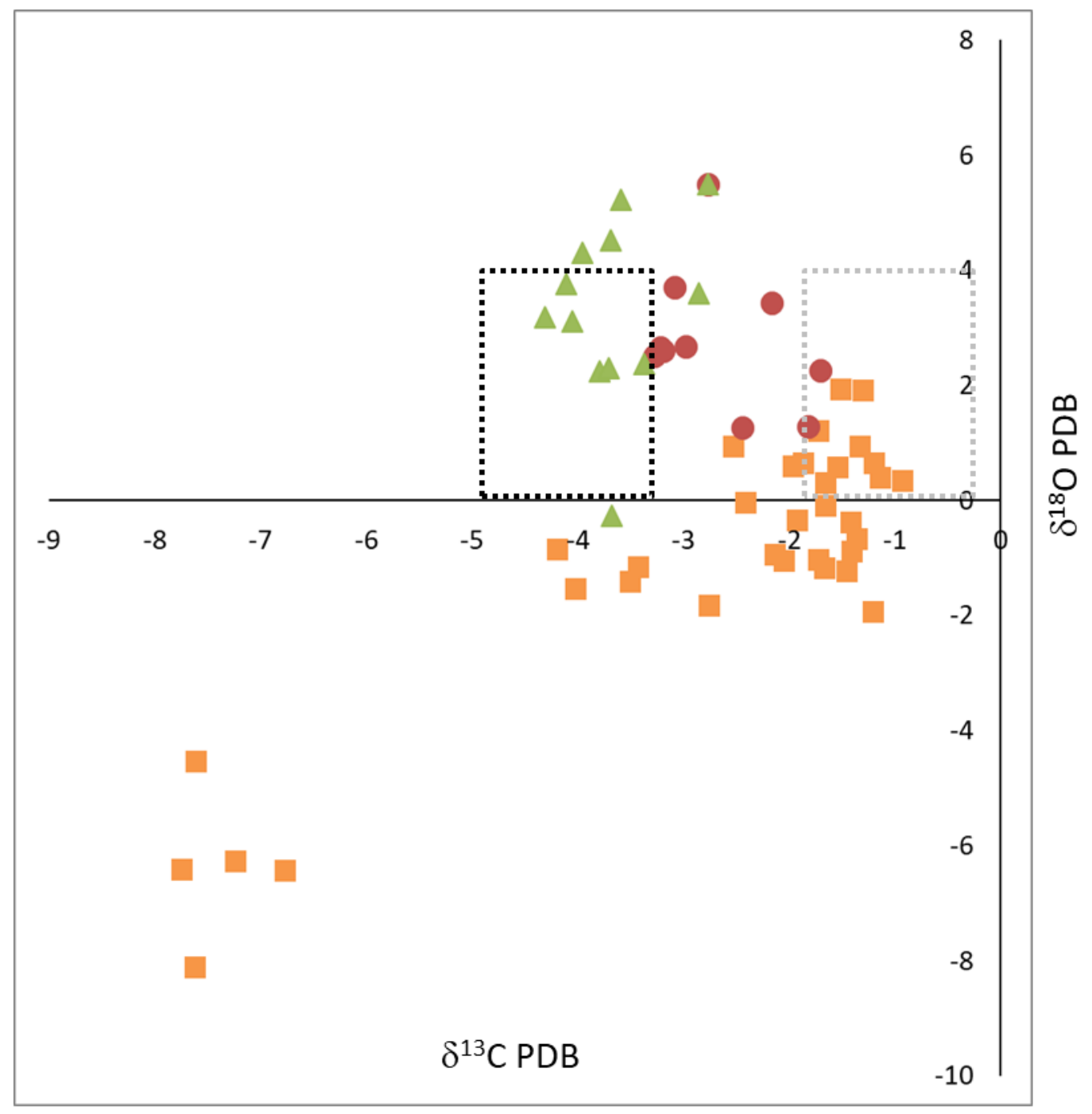


Figure 8

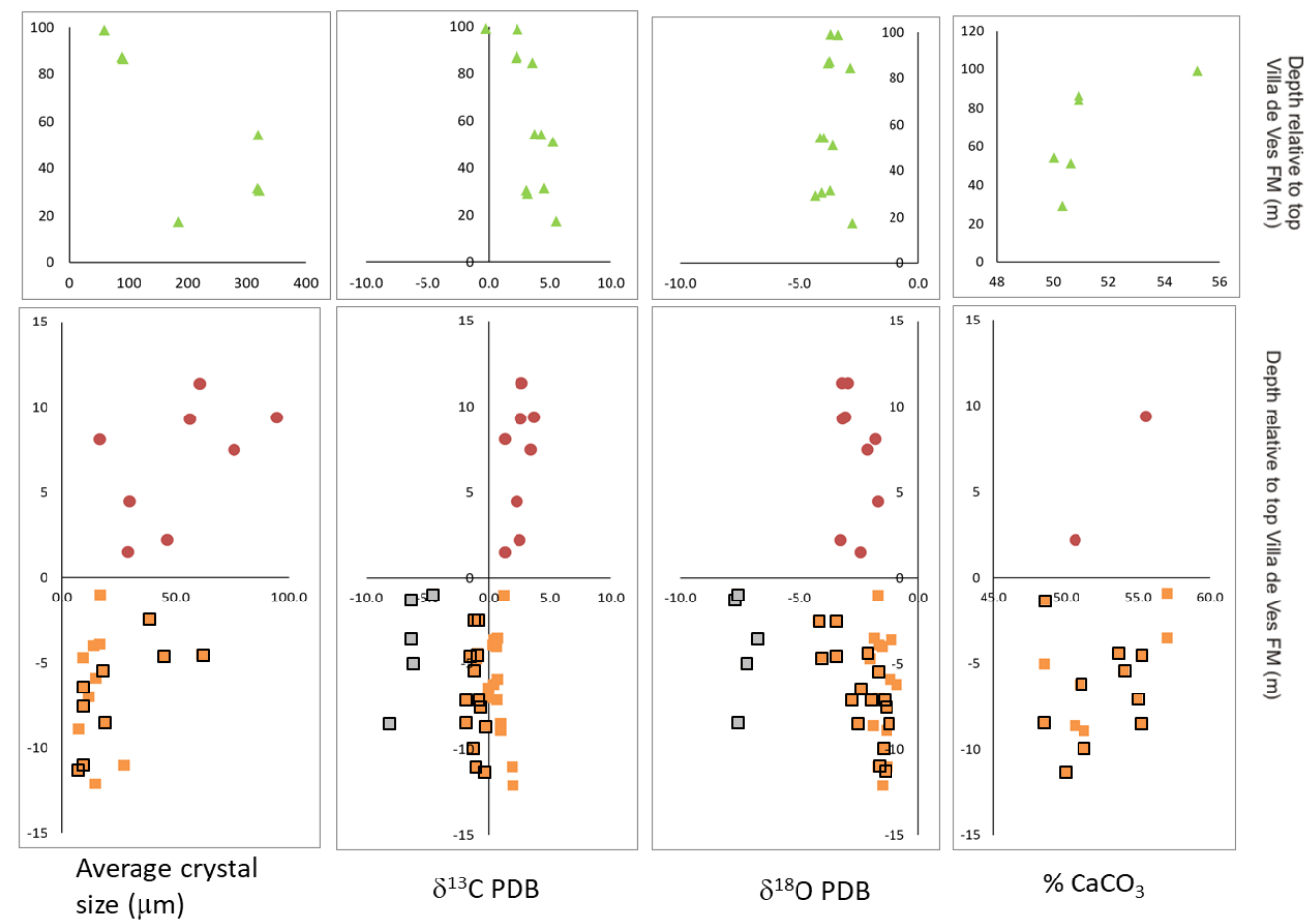


Figure 9

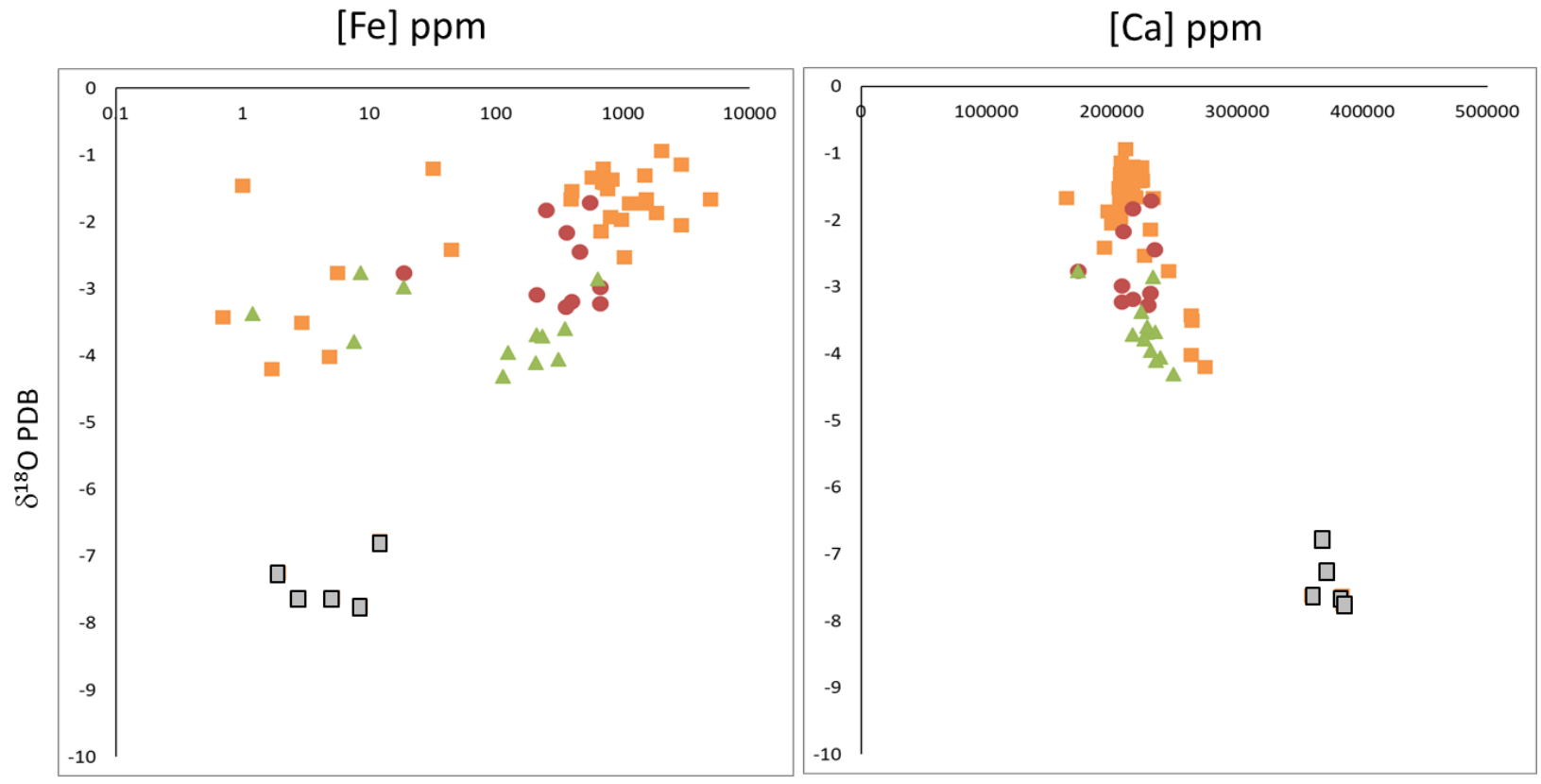


Figure 10
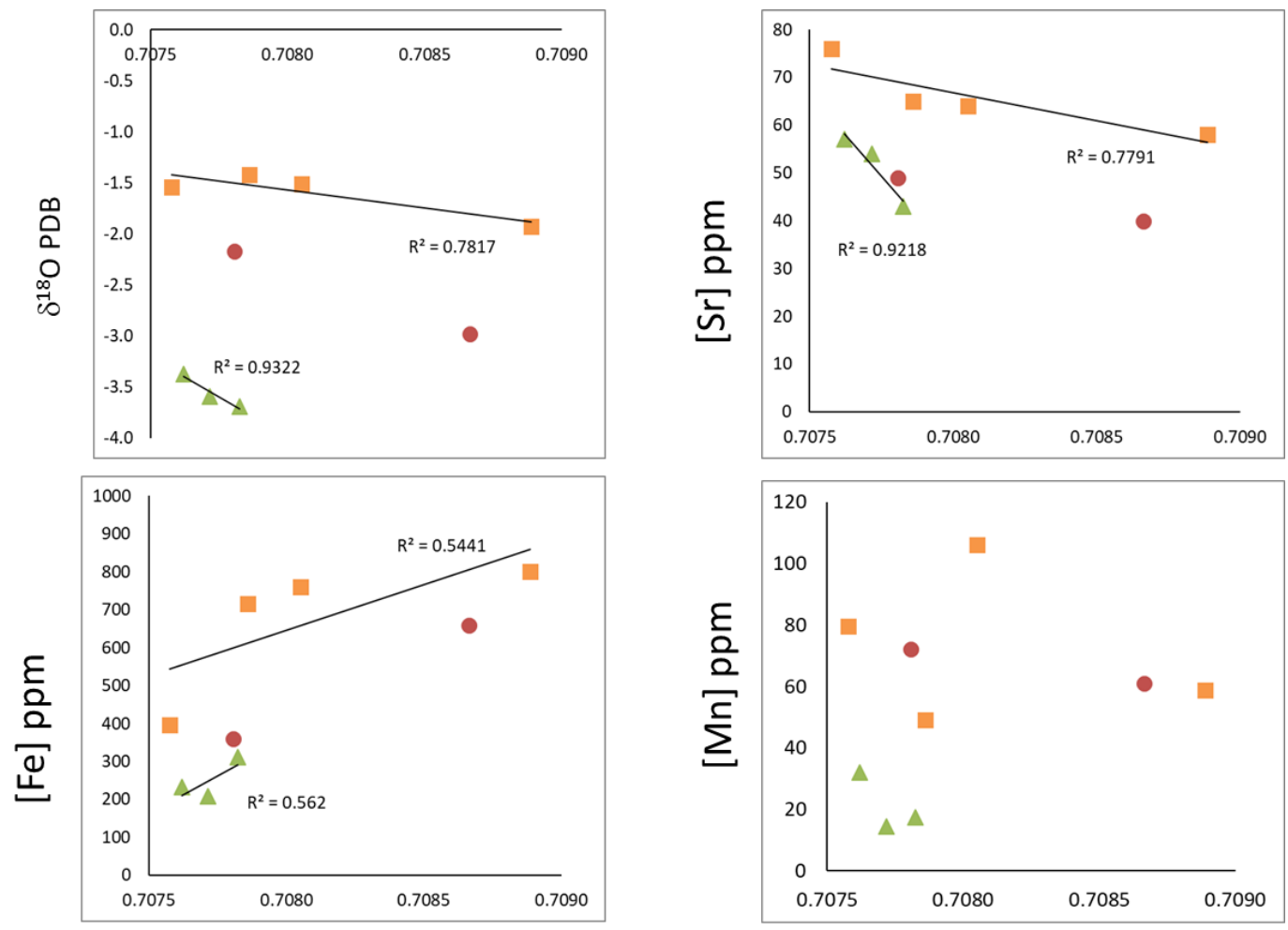

${ }^{87} \mathrm{Sr} /{ }^{86} \mathrm{Sr}$

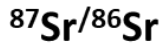


Figure 11
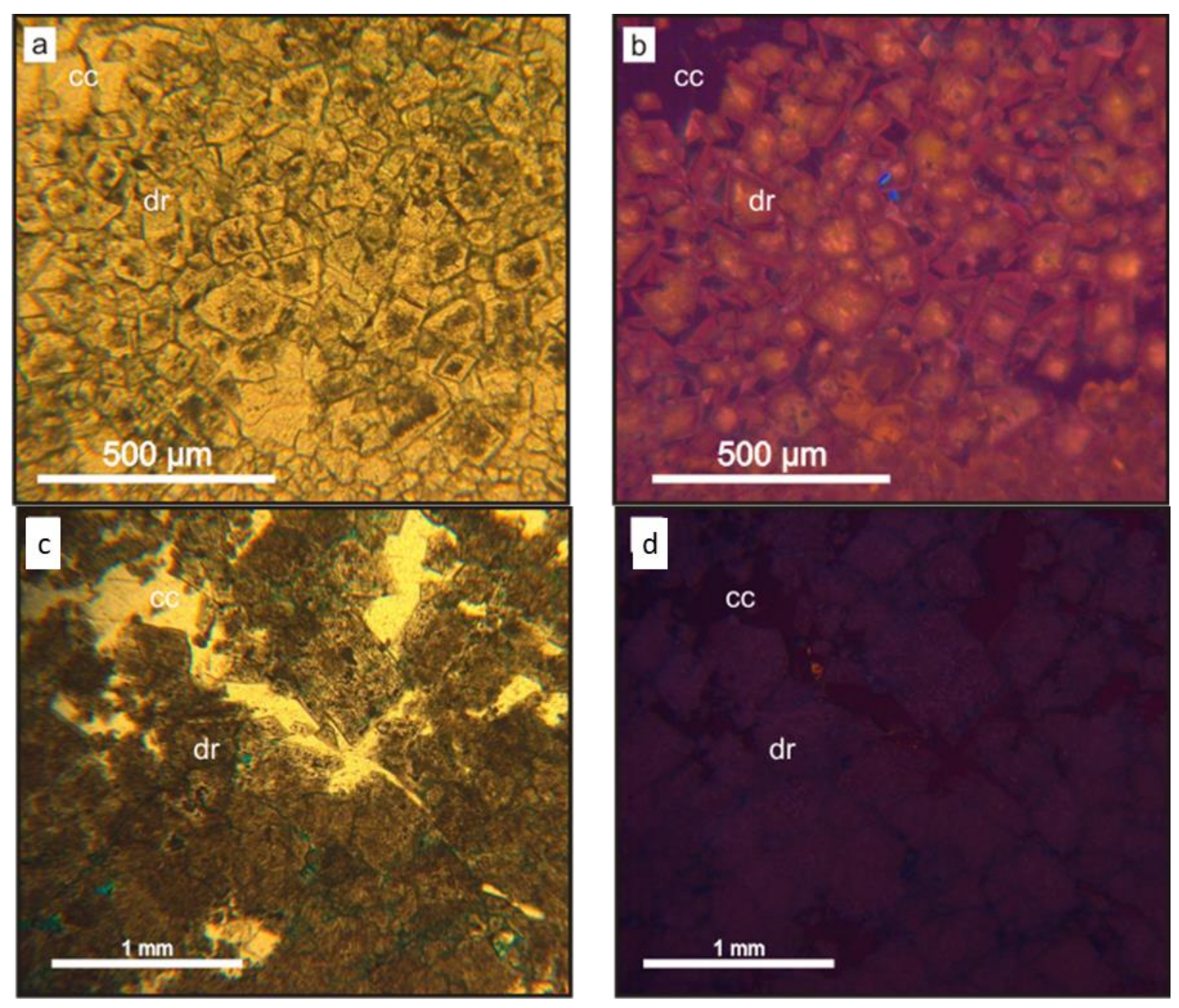
Figure 12
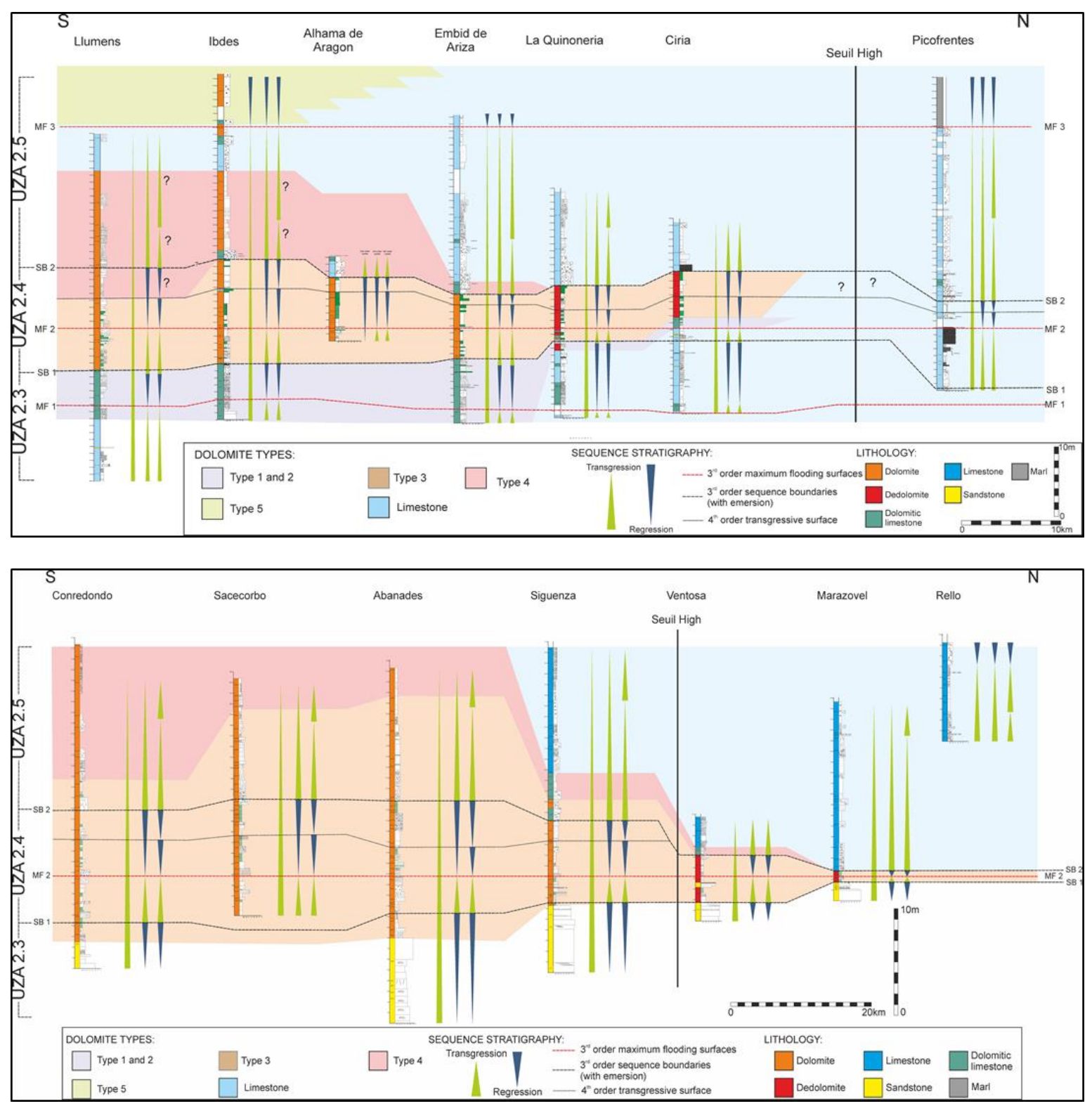
Figure 13
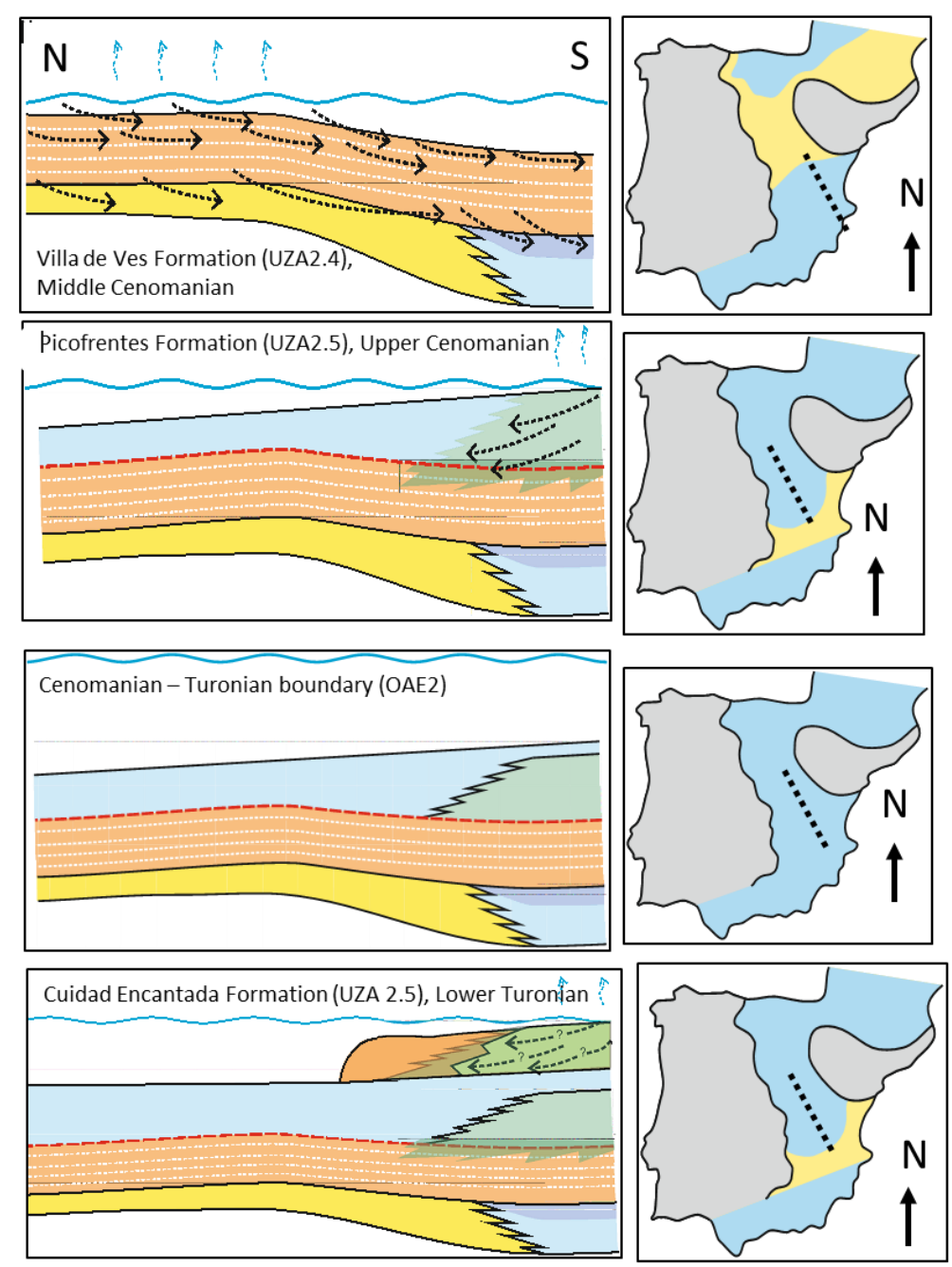

\begin{tabular}{|l|l|}
\hline$\square$ KEY & Limestone \\
$\square$ Dolomite type (i) and (ii) & Evaporation \\
$\square$ Sandstone with dolomite \\
cement
\end{tabular}

$\square$ Exposed land massif
$\square$ Shallow carbonate shelf
$\square$ Exposed sheff


Table 1

\begin{tabular}{|c|c|c|}
\hline \multirow{2}{*}{ Section } & \multicolumn{2}{|c|}{ Location } \\
\hline & Latitude & Longitude \\
\hline Llumens & $\mathrm{N} 41^{\circ} 08014$ & W01 ${ }^{\circ} 46507$ \\
\hline Ibdes & $\mathrm{N} 41^{\circ} 13381$ & $W 01^{\circ} 49043$ \\
\hline Alhama & N441 18048 & $W 01^{\circ} 52564$ \\
\hline Embid de Ariza & $\mathrm{N} 41^{\circ} 22573$ & W01 ${ }^{\circ} 57577$ \\
\hline La Quinoneria & $\mathrm{N} 41^{\circ} 33492$ & $W_{02}^{\circ} 02495$ \\
\hline Ciria & N413ㄱ197 & $\mathrm{W} 02^{\circ} 00382$ \\
\hline Picofrentes & $\mathrm{N} 41^{\circ} 46596$ & $W_{02}^{\circ} 33480$ \\
\hline Anquel del Ducado & N40.59381 & $W 02^{\circ} 06121$ \\
\hline Conredondo & $\mathrm{N} 40^{\circ} 47097$ & W02 32236 \\
\hline Sacecorbo & $\mathrm{N} 40^{\circ} 49464$ & W02 24542 \\
\hline Abanades & $\mathrm{N} 40^{\circ} 53392$ & W02 29371 \\
\hline Siguenza & $\mathrm{N} 41^{\circ} 02043$ & W02 ${ }^{\circ} 41380$ \\
\hline Ventosa & N41.10088 & W02 33324 \\
\hline Marazovel & $\mathrm{N} 41^{\circ} 18329$ & W02 44094 \\
\hline Rello & $\mathrm{N} 41^{\circ} 20362$ & $W 02^{\circ} 47040$ \\
\hline
\end{tabular}


Table 2

\begin{tabular}{|c|c|c|c|c|c|c|}
\hline Phase & Distribution & Morphology & $\begin{array}{l}\text { Cement }(\mathrm{C}) \text { or } \\
\text { replacement } \\
\text { (R) }\end{array}$ & $\mathrm{CL}$ & Size & Inclusions \\
\hline Type (i) & $\begin{array}{c}\text { Upper Santa Maria de los Hoyas } \\
\text { Formation (east) }\end{array}$ & Planar-e/p & $\mathrm{R}$ & $\begin{array}{l}\text { Dull orange to } \\
\text { non-luminescent }\end{array}$ & $\begin{array}{c}50 \mu \mathrm{m} \text { to } \\
75 \mu \mathrm{m}\end{array}$ & Clear \\
\hline Type (ii) & $\begin{array}{c}\text { Upper Santa Maria de los Hoyas } \\
\text { Formation (east) }\end{array}$ & Planar-e & C & $\begin{array}{c}\text { Dull orange to } \\
\text { non-luminescent }\end{array}$ & $\begin{array}{l}50 \mu \mathrm{m} \text { to } \\
100 \mu \mathrm{m}\end{array}$ & Clear \\
\hline Type (iii) & $\begin{array}{l}\text { Santa Maria de los Hoyas } \\
\text { Formation (west) } \\
\text { Villa de Ves Formation } \\
\text { Lower Picofrentes (west) }\end{array}$ & Planar-e/s & $\mathrm{R}$ and $\mathrm{C}$ & $\begin{array}{l}\text { Dull orange to dull } \\
\text { red }\end{array}$ & $\begin{array}{c}10 \mu \mathrm{m} \text { to } \\
50 \mu \mathrm{m}\end{array}$ & $\begin{array}{l}\text { Cloudy to } \\
\text { clear }\end{array}$ \\
\hline Type (iv) & $\begin{array}{l}\text { Lower and middle Picofrentes } \\
\text { Formation }\end{array}$ & Planar-e & $\mathrm{R}$ & $\begin{array}{l}\text { Dull yellow core } \\
\text { and dull red rim }\end{array}$ & $\begin{array}{l}50 \mu \mathrm{m} \text { to } \\
100 \mu \mathrm{m}\end{array}$ & $\begin{array}{c}\text { Cloudy } \\
\text { core/clear rim }\end{array}$ \\
\hline Type (v) & $\begin{array}{c}\text { Ciudad Encantada Formation } \\
\text { (east) }\end{array}$ & Planar-e/s & $\mathrm{R}$ and $\mathrm{C}$ & Non-luminescent & $\begin{array}{l}250 \mu \mathrm{m} \text { to } \\
300 \mu \mathrm{m}\end{array}$ & Very cloudy \\
\hline
\end{tabular}


Table 3

\begin{tabular}{|c|c|c|c|c|c|c|c|c|c|c|c|c|c|c|c|c|c|c|c|c|c|}
\hline \multirow[b]{2}{*}{ Phase } & \multicolumn{3}{|c|}{$\% \mathrm{CaCO}_{3}$} & \multicolumn{3}{|c|}{$\mathrm{Fe}$} & \multicolumn{3}{|c|}{$\mathrm{Mn}$} & \multicolumn{3}{|c|}{$\mathrm{sr}$} & \multicolumn{3}{|c|}{$\delta^{180}$} & \multicolumn{3}{|c|}{$\delta^{13} \mathrm{C}$} & \multicolumn{3}{|c|}{${ }^{87} \mathrm{Sr} \mathrm{r}^{86} \mathrm{Sr}$} \\
\hline & Min. & Max. & $\begin{array}{c}\text { Mea } \\
n\end{array}$ & Min & Max. & $\begin{array}{c}\text { Mea } \\
\mathrm{n}\end{array}$ & Min. & Max. & $\begin{array}{c}\text { Mea } \\
n\end{array}$ & Min. & Max. & $\begin{array}{c}\text { Mea } \\
\mathrm{n}\end{array}$ & Min. & Max. & $\begin{array}{c}\text { Mea } \\
\mathrm{n}\end{array}$ & Min. & Max. & $\begin{array}{c}\text { Mea } \\
\mathrm{n}\end{array}$ & Min. & Max. & Mean \\
\hline Type (i) & & & & & & & & & & & & & & & & & & & & & \\
\hline Type (ii) & & & & & & & & & & & & & & & & & & & & & \\
\hline Type (iii) & 50.0 & 55.2 & 52.9 & 1 & 1409 & 972 & 34 & 141 & 73 & 57 & 168 & 88 & -4.20 & \begin{tabular}{|l|} 
\\
\end{tabular} & -1.21 & -1.93 & 1.94 & -0.16 & 0.70758 & $\begin{array}{c}0.7088 \\
9\end{array}$ & $\begin{array}{c}0.7080 \\
9\end{array}$ \\
\hline Type (iv) & 50.6 & 55.1 & 53.0 & 208 & 551 & 429 & 51 & 72 & 61 & 40 & 123 & 68 & -3.28 & -1.71 & -2.68 & 1.28 & 3.78 & 2.64 & 0.70781 & $\begin{array}{c}0.7086 \\
6\end{array}$ & $\begin{array}{c}0.7082 \\
3\end{array}$ \\
\hline Type (v) & 50.0 & 55.2 & 51.3 & 1 & 639 & 185 & 12 & 52 & 28 & 38 & 111 & 58 & -4.31 & -2.77 & -3.66 & -0.27 & 5.50 & 3.32 & 0.70762 & $\begin{array}{c}0.7078 \\
3\end{array}$ & $\begin{array}{c}0.7077 \\
2\end{array}$ \\
\hline $\begin{array}{c}\text { De- } \\
\text { dolomite }\end{array}$ & & & & 0.4 & 12 & 5.1 & 23 & 196 & 73.3 & 11 & 129 & 37 & -7.75 & -6.77 & $\mid-7.39$ & -8.11 & -0.71 & -5.41 & & & \\
\hline
\end{tabular}

